\title{
PERTARUHAN PENTING: HERMENEUTIKA INSIDER MOVEMENT DAN INJIL*
}

\author{
David B. Garner \\ Westminster Theological Seminary, Philadelphia
}

\begin{abstract}
This article deals with Insider Movement. Is Insider Movement's interpretation and application of the interface of apostolic method and 1st-century religion rich rediscovery or radical redefinition? Capitalizing on McGavran's categories IM advocates have advanced extant socio-religious identity to a place of functional stasis and prominence, so that following Jesus means appropriating him within the boundaries of existing religions. In such IM method, the cultural how of missions effectively replaces the authoritative whom of missions. Is the IM gospel then a true gospel?
\end{abstract}

KEYWORDS: Insider Movement, missions, culture, hermeneutic, gospel.

ABSTRAK: Artikel ini membahas tentang Gerakan Dalam/ Insider movement. Apakah interpretasi dan penerapan Insider Movement atas metode apostolik dan agama abad pertama merupakan suatu penemuan kembali (rediscovery) yang limpah atau suatu pendefinisian ulang (redefinition) yang radikal? Dengan memanfaatkan kategori-kategori McGavran, para pendukung IM telah mengembangkan lingkup identitas sosio-agama hingga mencapai sebuah tempat penting dan kondisi fungsional yang statis, sehingga mengikuti Yesus berarti menempatkan Dia di dalam batasanbatasan agama yang sudah ada. Dengan metode IM seperti ini, pertanyaan budaya mengenai bagaimana misi dapat menggantikan pertanyaan untuk

\footnotetext{
* Artikel asli dalam bahasa Inggris dapat dilihat di David B. Garner, "High Stakes: Insider Movement Hermeneutics and the Gospel", Themelios 37 (2012): 249-74. Terjemahan bahasa Indonesia oleh David Tong dan Junedy Lee, editor Edward Oei.
} 
siapakah misi tersebut dilakukan. Apakah injil IM merupakan injil yang sejati?

KATA KUNCI: Gerakan Dalam, misi, kebudayaan, hermeneutika, injil.

\section{Muslim Mesianis dan Muslim Injili}

Apakah itu IM?

Di bulan Juni 2011, sinode Presbyterian Church in America (PCA) menerbitkan sebuah overture berjudul, "Panggilan Untuk Menjadi Saksi yang Setia". ${ }^{1}$ Selain memberikan peringatan terhadap terjemahan Alkitab yang menggunakan istilah-istilah yang digunakan dalam kekeluargaan untuk Tuhan (Anak, Bapa) dengan istilah-istilah yang tidak terlalu ofensif di dalam bahasa terjemahan, artikel ini juga memberikan perhatian gerejawi terhadap pendekatan-pendekatan misi yang semakin populer dan dikenal sebagai Gerakan Dalam (Insider Movements/IM). ${ }^{2}$ Beberapa orang

\footnotetext{
1 Artikel 9 dari Rapat Umum PCA tahun 2011. Sebagaimana yang dibahas dalam artikel ini, moderator Rapat Umum PCA membentuk sebuah komite untuk mempelajari dan membuat sebuah laporan mengenai Gerakan Dalam. Laporan ini diterbitkan pada bulan Mei 2012, Bagian Pertamanya membahas terjemahan Alkitab dan bahasa kekeluargaan ilahi. Laporan tersebut juga mencakup naskah lengkap versi akhir dari Artikel 9. Anda dapat melihatnya dengan judul "A Call to Faithful Witness, Part One-Like Father, Like Son: Divine Familial Language in Biblical Translation", http://pcaac.org/Ad\%20Interim \%20on\%20Insider\%20Movements\%20Report\%205-17-12.pdf (diakses 21 Mei 2012).

2 Ada lebih dari satu versi dari Insider Movement, dan beberapa orang lebih memilih untuk menggunakan istilah Insider Movements. Dalam pembahasan kita, IM mencakup makna tunggal dan jamak. Penjelasan yang lebih lengkap mengenai IM serta pembelaan dan perdebatan mengenainya dapat ditemukan di berbagai terbitan Evangelical Mission Quarterly [EMQ], International Journal of Frontier Missiology atau International Journal of Frontier Missions [IJFM], dan St. Francis Magaize [SFM]. Untuk pendekatan yang lebih simpatik terhadap IM, lihatlah kumpulan artikel di http://www.thepeopleofthebook.org/strategyInsiderArticles.html (diakses 28 Mei 2012); lihat juga, Kevin Higgins, “The Key to Insider Movements: The 'Devoteds' in Acts," IFJM 21:4 (2004): 155-165. Akhir-akhir ini ada 18 penulis yang mengkritik IM dalam buku yang berjudul Chrislam: How Missionaries are Promoting an Islamized Gospel (editor Joshua Lingel, Jeff Morton, dan Bill Nikides; Garden Grove: i2 Ministries, 2011). Sebuah kritikan pengantar terhadal IM yang lebih sederhana tetapi berguna, lihatlah Jeff Morton, Insider Movements: Biblically Incredible or Incredibly Brilliant? (Eugene: Wipf \& Stock, 2012). Untuk pembahasan mengenai tanggapan langsung antara pendukung dan lawan dari IM, lihatlah secara
} 
menyebutnya sebagai Gerakan Yesus (Jesus Movements), ${ }^{3}$ metode-metode yang kontroversial ini telah mendapatkan perhatian di tempat-tempat di mana ajaran Injil Kristen telah mendapatkan perlawanan yang keras. Karena sedikitnya hasil yang dicapaikan di tempat-tempat seperti Bangladesh dan negara-negara lainnya di mana Islam, Budha, atau Hindu mendominasi,4 para misionaris kaum Injili telah menggunakan teknik IM sejak tahun 1980an. Sekitar tahun 1990-an, popularitas IM berkembang ke seluruh dunia ketika banyak praktisi misionari menjadi tertarik dengan metode-metode IM. ${ }^{5}$ Selama dua dekade pembentukan ini, berbagai bentuk praktik IM telah menjadi arus utama, melewati batasan-batasan organisasi dan denominasi, dan sekarang telah membentuk banyak pola dari berbagai misi kaum Injili.

Para pendukung IM telah bersumbangsih dengan mencoba untuk memperbaiki kelemahan-kelemahan misi tertentu dan telah mengimplementasikan metodologi kesadaran diri yang lebih besar, yang bertujuan untuk menghentikan penggunaan kebudayaan barat di dalam kekristenan yang tidak disadari. ${ }^{6}$ Kita tidak akan membahas keberhasilan

keseluruhan terbitan dari St. Francis Maganize 5:4 (2009).

3 Lihat Kevin Higgins, "Discipling the Nations and the Insider Movement Coversation", Mission Frontiers 33:1 (Januari-Februari 2011): 26-27. Beberapa pembahasan mencakup, "Movements to Jesus within Islam (Buddhism, Hiduism)", "kingdom movements to Jesus", "Jesus movements that multiply disciples obedient to the Bible within different religious traditions", "the Kingdom paradigm", dan "incarnational movements". Bandingkan dengan Morton, Insider Movements, 5.

4 Agar lebih jelas, kita akan memusatkan pembahasan kita hanya pada IM di dunia Muslim.

$5 \quad$ Yang mirip dengan IM adalah C-5 dari taksonomi Skala-C yang diciptakan oleh John Travis (“Must All Muslims Leave Islam to Follow Jesus?" EMQ 34 [1998] 411-15). Skala-C ini membahas spektrum atau lingkup ekspresi iman dari orang percaya yang berlatar belakang Muslim (Muslim background believers/MBBs), di mana " $\mathrm{C}$ " menunjukkan sebuah jenis "komunitas yang berpusat pada Kristus" yang berbeda (Christ-centered community). Untuk memahami kritikan terhadap C-5, lihat Timothy C. Tennent, "Followers of Jesus (Isa) in Islamic Mosques: A Closer Examination of C-5 'High Spectrum' Contextualization”, IJFM 23:3 (2006): 101-15.

6 John Travis, seorang pendukung IM, berpendapat bahwa istilah-istilah Kristen dan kekristenan mengandung kecenderungan yang bersifat antitesis terhadap Injil. “Di dalam konteks Muslim, kata 'Kristen' ... berarti kebudayaan Barat, peperangan (Perang Salib), 
dari pengoreksian terhadap imperialisme kebudayaan tersebut. Yang menjadi perhatian kita adalah aspek-aspek pemikiran IM yang lebih kontroversial. Banyak pendukung IM mendesak supaya orang Muslim yang telah berpaling kepada Kristus seharusnya tetap memegang teguh berbagai praktik-praktik Islam dan menghindari sama sekali penggunaan identitas "Kristen". Penghindaran identitas ini melebihi sekadar persoalan istilah karena petobat ini diminta untuk tetap berada di dalam (memeluk) agama Islam dan mempertahankan identitas dan kebudayaan Islam mereka. Dapat dikatakan bahwa kebanyakan pendukung IM bermaksud agar "orang-orang dalam" (insiders) ini tidak hanya menjalankan praktik-praktik kebudayaan dan keagamaan mereka begitu saja, tetapi mereka lakukan semua ini dengan tujuan untuk merombak tradisi-tradisi agama ini dan menunjukkan Isa-Masih (Yesus Sang Mesias) kepada sesama rekan Muslim mereka. ${ }^{7}$ Sebagian pendukung IM menyatakan bahwa para misionaris Kristen seharusnya "masuk" ke dalam batasan-batasan sosial dan keagamaan dengan cara pindah agama menjadi Islam, dan bahkan beberapa misionaris barat menjadi Muslim untuk menyampaikan berita tentang Yesus. ${ }^{8}$

kolonialisme dan imperialisme". Orang Islam "mengasosiasikan kekristenan ... [dengan] aspekaspek buruk dari kebudayaan Barat di masa kini misalnya cara berpakaian yang tidak sopan, pergaulan seks, sikap tidak hormat kepada mereka yang lebih tua, kecanduan alkohol, kekerasan Hollywood, narkotika, dan pornografi” (John Travis, “Messianic Muslim Followers of Isa", IJFM 17:1 [2000]:53-59). Bandingkan J. T. Smith, "How Islamic Can Christianity Be?" http://thegospelcoalition.org/blogs/tgc/2012/05/14/how-islamic-can-christianity-be/ (diakses 28 Mei 2012).

7 Untuk pembahasan lebih lanjut mengenai berbagai metode ini, lihat karya Phil Parshall, "Danger! New Directions in Contextualization", EMQ 34:4 (1998): 404-10; Stan Guthrie, Missions in the Third Millenium: 21 Key Trends for the 21st Century (rev. ed.; Waynesboro, GA: Peternoster, 2005), 130-35; Warren C. Chastain, “Should Christians Pray the Muslim Salat?" IJFM 12:3 (1995): 161-63; Basil Grafas, "Insider Movements: An Evangelical Assesment", http://www.i2ministries.org/index.php?option=com_content\&view $=$ article\&id=120:insidermovements-an-evangelicalassessment\&catid=27:articles-category\&Itemid=72 (diakses $26 \mathrm{Mei}$ 2012).

8 Fakta ini telah dikonfirmasikan melalui surat menyurat langsung dengan misionarimisionari di daerah-daerah yang aman; metode-metode ini juga telah diterima, dalam tulisan John Travis, "Messianic Muslim Followers of Isa", 55. Tennent ("Followers of Jesus", 108) memberi catatan bahwa pendukung C-5, termasuk Travis, telah beralih dari mendorong orang- 
Sebagian lainnya menyatakan bahwa perspektif Islam yang benar menegaskan bahwa "agama yang dinyatakan oleh semua nabi (mis. Abraham, Musa, Daud, Yesus, dan Mohammad) pada awalnya adalah sama ... 'Islam yang sejati' adalah apa yang orang Kristen sejati percayai."9

Bagaimanakah perubahan paradigma misi seperti ini dapat terjadi? Walaupun terdapat banyak alasan dan penyebab, pada akhirnya praktik IM dapat diterima karena masalah keyakinan. Dengan menegaskan komitmen mereka kepada Alkitab, banyak yang percaya bahwa hanya metode IM saja yang menghormati integritas Injil, bahwa hanya gerakan ini sajalah yang menaati Roh Kudus di masa kini. Kenyataannya, para pendukung IM melihat metode misi mereka diizinkan dalam lingkup Alkitabiah, dan dimandatkan oleh Alkitab yang menunjukkan bagaimana Alkitab menjelaskan pola-pola apostolik. Apakah memang demikian? Apakah IM telah menggali mutiara terpendam di dalam sejarah misi, menyarikan keberhasilan-keberhasilan abad pertama yang dicatat di dalam Kisah Para Rasul? Apakah interpretasi dan penerapan (aplikasi) IM atas metode apostolik dan agama abad pertama merupakan suatu penemuan kembali (rediscovery) yang limpah atau suatu pendefinisian ulang (redefinition) yang radikal?

Yang mengendalikan pemikiran IM adalah sejumlah komitmen hermeneutika yang penting, dan ciri khas hermeneutika inilah yang akan menjadi fokus dari analisis kita. Kita dapat menemukan di antara petobat dan para praktisi misionari yang akan membela praktik IM dan memperlihatkan bukti keberhasilannya. Tetapi, baik peperangan anekdot maupun daftar keberhasilan dan kegagalan menyertai praktik IM. Pemikiran

orang Barat untuk menjadi Muslim demi penginjilan. Lihatlah karya Roger Dixon, “Moving on from the C1-C6 Spectrum", SFM 5:4 (2009): 14, diterbitkan kembali dalam Chrislam, 96.

9 Bernard Dutch, “Should Muslims Become 'Christians'?” IFJM 17:1 (2000):17. Salah satu isu yang diperdebatkan di antara pendukung IM adalah keabsahan kenabian Mohammad. 
IM perlu untuk dibahas menurut Alkitab, sebagaimana para pendukung IM sendiri telah menyadari kebutuhan ini. Ketika kritik semakin banyak, para pembela IM secara terbuka membela praktik IM, menghasilkan cerita-cerita dan statistik, serta berargumen menurut Alkitab. Pembelaan semacam ini berasal dari para pakar misiologi dan misionaris, kebanyakan dari mereka memiliki kaitan yang erat dengan pakar misiologis terkenal dari Fuller Seminari, seperti Donald McGavran. Karena fondasi Fuller tidak terpisahkan dari IM maka sebelum kita dapat membahas bentuk-bentuk hermeneutisnya, secara memadai, kita harus memahami dorongan dari bentuk-bentuk ini secara historis dan konseptual - yaitu misiologi dan antropologi McGavran dan rekan-rekannya.

\section{Suatu Peta Baru untuk Misi}

Di akhir hidupnya, McGavran, dengan seluruh pengaruh misiologinya, menyerukan perlunya suatu "langkah besar" bagi penggunaan batas-batas masyarakat misionaris baru untuk "berfokus kepada tugas penginjilan dunia yang belum selesai!" 10 Di dalam permohonan yang mendesak ini, McGavran menyatakan bahwa semangat misi untuk menjangkau orang-orang yang belum terjangkau hanya dapat berhasil kalau digabungkan dengan mobilisasi yang taktis dan disengaja. Emosi tanpa strategi adalah kosong, dan sebagaimana dia menilai keadaan misi pada zamannya, struktur misi yang ada tampak jelas sangat tidak memadai untuk tugas monumental ini. "Kecuali jika secara harfiah ada ribuan masyarakat misionaris baru didirikan di ribuan gereja lokal (denominasi) di Amerika, maka 'orang-orang yang belum terjangkau' tidak akan dapat dijangkau." 11 Walaupun kalimat tersebut terlalu membesarbesarkan ketergantungan yang terlalu terpusat pada Amerika atas

10 Donald A. McGavran, "A Giant Step in Christian Missions", Mission Frontiers 1:3 (1985): 3133.

11 Ibid., 32. 
keberhasilan penginjilan di dunia, kita harus menghargai visi dan semangat McGavran.

McGavran membuktikan dirinya sebagai seorang pemikir dan ahli strategi yang berani dan unik, seorang pendukung analisis budaya yang kreatif dan seseorang yang memperhatikan koreksi-koreksi misi. Dengan cara yang mirip dengan dan bersimpatik terhadap formulasi yang kontroversial dari sesama profesor di Fuller yang bernama Charles Kraft, McGavran secara paradigmatis bergantung kepada penelitian antropologi kebudayaan dan sosiologi. ${ }^{12}$ Dengan menilai semangat dan analisisnya, kita juga seharusnya memperhatikan definisinya yang berbahaya mengenai "orang yang tidak terjangkau". Di balik panggilan untuk mobilisasi dan suatu perbedaan yang mencolok antara orang yang telah dijangkau dan yang tidak terjangkau, tersembunyi suatu konsep sosiologi yang telah melahirkan desakan kuat kepada IM. McGavran menyatakan,

Suatu suku bangsa atau bagian masyarakat "yang tidak terjangkau" adalah seseorang yang merupakan pengikut Kristus dinilai oleh rekan mereka sebagai orang yang telah "meninggalkan dan mengkhianati kaumnya sendiri untuk bergabung dengan kaum lain". Secara positif, seseorang dianggap sebagai orang yang terjangkau ketika mereka telah menjadi Kristen, mereka masih dianggap oleh rekan mereka sebagai "masih merupakan kaum kami sendiri yang sedang menunjuk kepada jalan yang mereka anggap sebagai jalan yang baik untuk kami ikuti". ${ }^{13}$

Penyimpangan yang mengkhianati kekristenan ini, yang disesali oleh McGavran dalam karya yang berjudul The Bridges of God yang terbit pada

12 Lihat, misalnya, Donald McGavran, Understanding Church Growth (Grand Rapids: Eerdmans, 1990), vii-xviii, 93-95. Lihat Charles H. Kraft, Christianity in Culture: A Study in Dynamic Theologizing in Cross-Cultural Perspective (Maryknoll: Orbis, 1979) dan Charles H. Kraft, Anthropology for Christian Witness (Maryknoll: Orbis 1996). Untuk pokok-pokok simpati dan kritik terhadap Kraft, lihat Harvie M. Conn, Eternal Word and Changing Worlds: Theology, Anthropology in Trialogue (Grand Rapids: Zondervan, 1984), 149-50, 167-76, 329-38.

13 McGavran, "Giant Steps", 31-32 (penekanan sesuai aslinya). 
tahun 1955, 14 yang menghasilkan dasar pemikiran awal untuk pengevaluasian ulang terhadap misiologi. Dengan tujuan untuk membahas "masalah" bagi petobat yang meninggalkan keluarga mereka dan identitas sosial mereka, dan berjalan mengikuti visi McGavran untuk dunia serta merasa cemas atas kegagalan-kegagalan misi dalam kebudayaankebudayaan yang menolak Injil, pakar-pakar misiologis seperti Charles Kraft, Ralph Winter, Kevin Higgins, John dan Anna Travis, Dudley Woodberry, dan Rebecca Lewis telah membuat peta perjalanan IM. Dengan memperluas batasan dari pengertian "kelompok-kelompok masyarakat" dari McGavran, mereka telah menemukan jalan untuk memberikan afirmasi kepada lingkup netralitas agama dan kebudayaan yang lebih luas. ${ }^{15}$ McGavran secara konsisten menolak pendekatan misiologis yang dibentuk oleh individualisme Barat, ${ }^{16}$ dan para pendukung IM telah meninggikan "kelompok masyarakat" dan "gerakan masyarakat" seperti itu menjadi sebuah paradigma yang penting, menekankan penerimaan yang lebih luas atas identitas dan praktik-praktik non-Kristen mereka, dan menganjurkan "keluarga orang yang percaya ... [untuk] tetap tinggal di dalam komunitas sosioagama mereka". ${ }^{17}$ Dengan memanfaatkan kategori-kategori McGavran, para pendukung IM telah mengembangkan lingkup identitas sosio-agama hingga

14 Donald McGavran menyatakan, “Untuk mengkristenkan seluruh orang, hal pertama yang tidak boleh dilakukan adalah merenggut individu-individu keluar dari masyarakatnya untuk memasukkannya ke dalam masyarakat yang berbeda" (Bridges to God: A Study in the Strategy of Missions [New York: Friendship, 1955], 10). McGavran, merespons individualisme yang masih mendominasi penginjilan di barat, membela "gerakan masyarakat" yang berusaha untuk memajukan iman Kristen dengan cara yang menyebabkan "hidup sosial dari seorang individu tidak dihancurkan" (16).

15 Untuk menyesuaikan diri dengan misiologi Fuller, para pendukung IM, mendefinisikan agama menurut pengertian norma-norma kebudayaan. Lihat, misalnya, Charles H. Kraft, "Is Christianity a Religion or a Faith?" di Charles H. Kraft, ed., Appropriate Christianity (Pasadena: William Carey Library, 2005), 83-97.

16 McGavran, Bridges, 16, 34, 68-99.

17 Rebecca Lewis, "Promoting Movements to Christ within Natural Communities", IJFM 24:2 (2007): 76 (penekanan huruf miring sesuai aslinya). 
mencapai sebuah tempat penting dan kondisi fungsional yang statis, ${ }^{18}$ sehingga mengikuti Yesus berarti menempatkan Dia di dalam batasanbatasan agama yang sudah ada.

Maka, menurut pemetaan misi IM, rute terbaik menuju diciptanya kumpulan dari pengikut Yesus yang bertumbuh adalah untuk bersikeras menuntut agar mereka (1) tetap berada di dalam kebudayaan, sosial, kekeluargaan, dan jaringan agama yang sudah ada, dan (2) tetap memelihara identitas dan praktik-praktik agama mereka yang unik. Menyatakan bahwa kebanyakan pengertian orang Barat atas gereja sebagai "struktur gerejawi ciptaan manusia", 19 perancang IM memanggil kita untuk menerima dan mempromosikan komunitas-komunitas non-Kristen pengikut Yesus semacam ini. Semua jalan mungkin tidak menuju kepada Yesus, tetapi Roh dari Yesus pasti membakar jejak keselamatan melalui cara-cara nonKristen yang tidak biasa. ${ }^{20}$

\section{Allah dan Para Rasul: Orang-orang Dalam (Insiders) Pertama?}

Keyakinan para pendukung IM yang menyebutkan diri mereka

\footnotetext{
18 Kita tidak boleh mengabaikan perubahan-perubahan teologi kontemporer yang korelatif di Seminari Fuller pada zaman ini. Dengan menegaskan dirinya yang berkomitmen terhadap ineransi Alkitab pada tahun 1947, Fuller secara terbuka meninggalkan komitmennya terhadap ineransi Alkitab sepenuhnya pada tahun 1965. Sejalan dengan semakin meningkatnya ketergantungan kepada antropologi kebudayaan dan sosiologi, kepercayaan kepada Alkitab juga semakin menghilang. Pergeseran otoritas ini mewakili sebuah paradigma epistemologi, hermeneutika, dan metodologi (misi) yang sangat berbeda. Lihat George Marsden, Reforming Fundamentalism: Fuller Seminary and the New Evangelicalism (Grand Rapids: Eerdmans, 1987; cetak ulang 1995); Noman L. Geisler dan William C. Roach, Defending Inerrancy: Affirming the Accuracy of Scripture for a New Generation (Grand Rapids: Baker, 2011), 17-24.

19 Rebecca Lewis, "Can the Kingdom of God Break Out of Christendom? Expecting the Unexpected", Missions Frontiers 33:3 (Mei-Juni 2011): 15.

20 Sebagian pendukung IM menyatakan secara eksplisit natur sementara dari Islam "Mesianis", di mana praktik-praktik seperti "kehadiran masjid hanya dapat menjadi bagian transisi dari perjalanan spiritual sebagian kaum percaya golongan C5" (John Travis, "Messianic Muslim Followers of Isa," 55). Ciri transisional IM atau praktik C5 ini tidak dimiliki oleh semua ataupun dinyatakan secara eksplisit oleh kebanyakan dari mereka.
} 
sebagai kaum injili sungguh sangat teguh: "Yang sebenarnya merupakan intisari dari paradigma gerakan dalam ini (insider movement) adalah Allah yang sedang bekerja secara langsung di antara bangsa-bangsa, termasuk dalam agama-agama mereka, untuk membuat di setiap bangsa menjadi kaum kepunyaan-Nya. Ini semua adalah gerakan-Nya, dan Dia adalah Orang Dalam (Insider) yang sesungguhnya."21 Bagi teoritikus dan pelaku IM, memproklamasikan Injil kepada orang-orang yang tak terjangkau di zaman ini memerlukan metode-metode pengoreksian ini, yang menurutmu merupakan metode-metode yang meniru perilaku para rasul. Pakar misiologis IM menganggap diri mereka sedang memperbarui dan memulihkan misi Alkitabiah. Dengan usaha untuk meniru metode apostolik yang berani, pendukung IM bertanya, apa yang benar-benar Yesus lakukan? Apa yang dilakukan oleh para rasul? Apa yang dilakukan oleh gereja mulamula? Dan apa yang akan mereka lakukan sekarang untuk menjangkau orang-orang yang memiliki identitas kebudayaan dan agama yang sepenuhnya bersifat non-Kristen? Apa yang akan mereka lakukan untuk menjangkau orang-orang yang identitas, relasi, dan keberadaannya hidup dalam konteks non-Kristen, bahkan anti-Kristen ini?

Dengan merenungkan perkataan Paulus yang penuh semangat misi dari Paulus ("aku menjadi") di 1 Korintus 9, J. Dudley Woodberry, Profesor Studi Islam di School of Intercultural Studies di Seminari Teologi Fuller, mengangkat pertanyaan mengenai aplikasi dari metode apostolik abad ke21:

Jikalau Paulus sedang melakukan perjalanan misinya hari ini, akankah dia menambahkan, "Bagi orang Muslim, saya menjadi seorang Muslim"? ... Akankah dia dan Konsili Yerusalem menyetujui Muslim untuk boleh secara bebas mengikuti Yesus sambil memelihara identitas dan praktik-praktik Muslim, sejauh batasan yang diizinkan oleh komitmen tersebut, sebagaimana

21 Kevin Higgins, "Inside What? Church, Culture, Religion, and Insider Movements in Biblical Perspective", SFM 5:4 (2009): 91. 
pemimpin-pemimpin Yerusalem menyetujui orang Yahudi untuk secara bebas mengikuti Yesus sambil tetap memelihara identitas dan praktik-praktik Yahudi sejauh batasan yang diizinkan oleh komitmen tersebut? ${ }^{22}$

\section{Hermeneutika Insider Movement}

Rebecca Lewis dan Pembelaan IM ${ }^{23}$

Dengan pertanyaan-pertanyaan ini berdering di telinga kita, kita beralih kepada Rebecca Lewis, anak perempuan dari pakar misi Fuller lainnya, Ralph D. Winter. Di dalam tulisannya, Lewis telah berusaha untuk membela IM dan menjabarkan batasan-batasan yang sah. Dalam arti apakah identitas agama dan kebudayaan dapat atau seharusnya tetap tidak berubah ketika seseorang percaya kepada Yesus Kristus? Dalam arti apakah kita dapat "menyatakan bahwa Kristus memanggil orang-orang untuk mengubah hati mereka, bukan agama mereka"?24 Bukan hanya sebagai seorang teoretisi, tetapi juga sebagai praktisi yang berpengalaman di antara kaum Berber di Afrika Utara, Lewis dengan sadar memikirkan usaha misinya sendiri. Jumlah tulisannya yang semakin banyak diterbitkan, kebanyakan telah dapat diakses melalui internet, juga telah menambah pengaruhnya di dalam memperkenalkan dan mempraktikkan IM.

Sebelum kita membahas pemikirannya secara langsung, izinkan saya untuk memuji Lewis atas tulisannya yang jelas, hermeneutika umum yang

22 J. Dudley Woodberry, “To the Muslim I Became a Muslim?” IJFM 24:1 (2007):23.

Bandingkan dengan Brian K. Peterson, “The Possibility of a 'Hindu Christ-Follower': Hans Staffner's Proposal for the Dual Identity of Disciples of Christ within High Caste Hindu Communities", IJFM 24:2 (1988): 87-97. Georges Houssney memberikan kritik yang mendalam atas tesis Woodberry di “Would Paul Become Muslim to Muslims?” di Chrislam, 62-76.

23 Saya berterima kasih kepada Rebecca Lewis untuk tanggapannya terhadap versi awal dari analisis ini. Komentarnya telah membantu di dalam memperbaiki artikel ini dalam mencapai bentuk akhirnya.

24 Guthrie, Missions, 132-33. Perbedaan tajam antara agama dan relasi berfungsi sebagai paradigma di IM, mencerminkan kategori agama lawan iman yang dianut oleh Charles H. Kraft. Bandingkan, Tennet ("Followers of Jesus", 111) juga menyoroti "perangkap" karena menuruti dikotomi palsu "personal" lawan "proposisional". 
konsisten, dan presentasi yang energetik. Visinya yang sejalan dengan McGavran untuk penginjilan seluruh dunia dipadukan dengan penolakan untuk menerima batasan-batasan manusiawi terhadap pekerjaan Kerajaan Allah adalah suatu hal yang layak mendapatkan pujian. "Kita belum pernah melakukan hal tersebut sebelumnya" adalah suatu kalimat yang tidak sesuai dengan dan tidak dapat ditemukan di dalam pemikiran Lewis. Selain itu, walaupun sudah merupakan kebiasaan yang umum untuk mengisolasi berita Injil dari metode pemberitaan Injil, Lewis menekankan ketidakterpisahan keduanya.

Dengan menggunakan pendekatan hermeneutika dan metodologi dari pemikiran IM, pembelaan Lewis bagi IM dapat dilihat di dalam artikel yang berjudul, "The Integrity of the Gospel and Insider Movements". 25 Artikel ini akan menjadi titik rujukan utama kita, walaupun bukan satusatunya rujukan, dalam analisis kita, karena artikel ini telah menyaring argumen-argumen teologis dan misiologis utama yang membongkar hermeneutika IM. Orang-orang yang penasaran atau peduli terhadap IM akan mendapatkan penjelasan mengenai struktur interpretatif dan teologis IM, dan juga jendela kepada implikasi praktikalnya. Dengan memperhatikan para pengkritik IM secara saksama, Lewis memohon agar kita meninjau kembali bagaimana kita memahami Injil Kristen dan penilaian terhadap IM. Walaupun artikelnya tidak memberikan hal yang baru bagi pembahasan IM, interaksinya yang berlimpah dengan Alkitab, klaimklaimnya yang komprehensif, dan daya tariknya yang kuat menuntut respons kita. ${ }^{26}$ Terlebih lagi, walaupun Lewis telah menulis bagian-bagian

25 Rebecca Lewis, “The Integrity of the gospel and Insider Movements", IFJM 27:1 (2010): 4148, tersedia di http://www.ijfm.org/PDFs_IJFM/27_1_PDFs/27_1_Lewis.pdf (diakses 11 Juli 2012).

26 Dick Brogden, seorang misionaris yang menginjili kaum Muslim di Afrika, mengkritik artikel Rebecca Lewis sebelumnya ("Insider Movements: Honoring God-Given Identity and Community", IJFM 26:1 [2009]: 16-19), di mana dia menentang berbagai presuposisi IM. Lihat Brogden, "Inside Out: Probing Presupossitions among Insider Movements", IJFM 27:1 (2010): 33-40. Artikel ini sangat berguna, karena pengarang juga membahas respons dan komentar dari 
lain mengenai faktor sosiologis dalam misi ${ }^{27}$ dan topik-topik lain yang berkaitan dengan $\mathrm{IM}^{28}$ di dalam artikel ini dia secara eksplisit berusaha untuk membangun pembelaan Alkitabiah yang paling meyakinkan untuk filosofi dan metodologi IM.

Dengan meneliti beberapa teks Alkitab pilihan, Lewis secara eksplisit dan ambisius mengemukakan bahwa IM bukan hanya sebuah posisi yang Alkitabiah melainkan satu-satunya posisi yang Alkitabiah. Kevin Higgins, seorang pendukung IM lainnya yang terkenal, juga mendukung ambisi besar ini, dan memberikan nilai besar bagi kepentingan historis IM:

Saya percaya bahwa perdebatan mengenai Insider Movements sebenarnya merupakan perdebatan mengenai Injil, sebuah perdebatan yang berpotensi menjadi gerakan reformasi besar dan menggemparkan seperti reformasi Lutheran, Reformed, Anglikan, dan Anabaptis pada abad ke-16. Gerakangerakan ini didorong oleh penemuan kembali atas kebenaran-kebenaran Alkitabiah yang pokok dan mendasar seperti pembenaran oleh iman, Injil kasih karunia, keimamatan semua orang percaya, dan posisi Alkitab di dalam kehidupan gereja dan orang percaya. Dan mereka memaksa pemimpinpemimpin gereja untuk mengevaluasi kembali praktik dan doktrin gereja. ${ }^{29}$

\footnotetext{
Lewis atas kritiknya.

27 Lihat, misalnya, Rebecca Lewis, “Underground Church Movements: The Surprising Role of Women's Networks", IJFM 21:4 (2004): 145-50.

28 Lihat, misalnya, Rebecca Lewis, "Strategizing for Church Planting Movements in the Muslim World: Informal Reviews of Rodney Stark's The Rise of Christianity and David Garrison's Church Planting Movement", IJFM 21:2 (2004): 73-77; idem, "Promoting", 75-76; idem,

"Honoring", 16-19; idem, "Can the Kingdom", 15; idem, "Possible Pitfalls of Jesus Movements: Lesson from History", History Frontiers 33:3 (Mei-Juni 2011): 21-24.

29 Di atas dasar ini, Higgins menekankan keseriusan pernyataan IM: "Saya melihat Insider Movements sebagai pendorong (dan juga didorong oleh) penemuan ulang terhadap doktrin Inkarnasi, pendekatan yang sepenuhnya Alkitabiah terhadap kebudayaan dan agama, peran dari Roh Kudus di dalam memimpin umat Allah untuk 'melakukan' Injil dengan cara-cara yang baru, dan pengertian mengenai bagaimana Tuhan bekerja di dalam dunia di antara dan di luar umat perjanjian-Nya. Dan kita mungkin harus dipaksa untuk menilai ulang sebagian konsep dan praktik kita yang sudah dipegang selama ini" (Higgins, “Devoteds”, 155-56). Fakta bahwa Higgins memberikan penekanan kepada inkarnasi Kristus sebagai contoh misi daripada penebusan Kristus sebagai pengganti umat-Nya merupakan sebuah perbedaan teologis yang sangat besar.
} 
Dengan menyoroti pertambahan jumlah orang Muslim, Hindu, dan Budha yang kepadanya "Allah memberikan iman kepada Yesus Kristus" tetapi yang belum "menjadi 'Kristen' mengadopsi bentuk-bentuk atau identitas Kristen yang tradisional", ${ }^{30}$ Lewis menyatakan bahwa Insider Movements sebenarnya bukan sebuah hasil ciptaan para ahli misiologi, melainkan aktivitas spontan yang menuntut kita "untuk menilai apakah mereka memiliki keabsahan yang Alkitabiah". ${ }^{31}$ Peran dari para ahli misiologi dianggap bersifat pasif dan investigatif, bukan meyakinkan dan memperkenalkan. Apa pun sikap kita dan bagaimana pun kita melihat interpretasi terhadap asal mula IM ini, ${ }^{32}$ semakin bertambahnya tulisan yang diterbitkan, yang menunjukkan bahwa penulisan dan analisis terhadap hal ini bukanlah suatu hal yang bersifat pasif. Deskripsi telah menjadi preskripsi, dan bersama dengan analisis Higgins, argumentasi Lewis menimbulkan pertanyaan preskriptif terhadap praktik dan doktrin.

\section{Pertaruhan IM}

Salah satu tantangan di dalam interaksi dengan argumentasi IM adalah masalah kejelasan. Definisi, parameter teologi yang dapat dikenali, dan bahkan menjelaskan aplikasi dari pernyataan IM tetap sulit dipahami. Argumentasi IM menyampaikan beragam pernyataan yang menetapkan jalur tetapi tidak menetapkan secara eksplisit natur dari jalur tersebut.Tidakmendefinisikan tersebut tentunya disengaja, sebagaimana paradigma IM sejalan dengan paradigma "himpunan yang berpusat" ("centered set") dari

30 Lewis, "Integrity", 47. Lihat juga sebuah dasar historis yang dikembangkan Lewis bagi penyebaran Injil "di antara jaringan sosial yang sudah ada" ("Strategizing for Church Planting Movements", 75; "Honoring", 17-18).

31 Respons Rebecca Lewis di Brogden, "Inside Out", 33, catatan $a$. IM berulang kali menekankan bahwa IM dan pemikiran C-5 bersifat deskriptif, bukan preskriptif.

32 Kalaupun dapat ditunjukkan bahwa gerakan IM bersifat spontan (sebuah pernyataan yang dapat diperdebatkan), penilaian tersebut tidak memungkinkan untuk mengubah suatu analisis menjadi sistem, deskripsi menjadi preskripsi. Spontanitas tidak menunjukkan berkat ilahi. 
Paul Hiebert di mana gerakan menjadi definisi mengikuti Yesus. ${ }^{33}$ Percaya kepada Kristus bukanlah masalah doktrin (suatu "himpunan yang membatasi") saja, tetapi mengenai orientasi; itu bukanlah juga mengenai kepatuhan kepada kepercayaan-kepercayaan tertentu sesuai dengan batasan-batasan yang sudah ditetapkan, tetapi merupakan proses menuju kepada pusat, Yesus Kristus ("himpunan yang berpusat"). Lewis berjalan menurut pemikiran ini. Walaupun tentunya dia tidak menanggap semua praktik keagamaan dapat diterima oleh seorang pengikut Kristus, komitmen yang besar terhadap batasan-batasan yang tidak didefinisikan mengakibatkan contoh-contoh kontemporer yang spesifik atau alat-alat yang dapat dipakai untuk menganalisis pertanyaan tersebut dihindari; melakukan hal ini sama dengan menegakkan batasan-batasan yang tidak tepat di mana konsep mengenai batasan-batasan tersebut mengacaukan paradigma IM. Tetapi ironisnya, orientasi himpunan yang berpusat ini sendiri dibatasi oleh komitmen untuk menjaga tidak ada batasan yang definitif. ${ }^{34}$

Pada tahun 2007, Lewis menjelaskan jalur IM berkaitan dengan sifatnya yang non-Barat, komunal, dan non-tradisional: "'insider movement'

33 Untuk penjelasan mengenai paradigma himpunan-yang-membatasi dan yang terpusat, lihat Paul G. Hiebert "Coversion, Culture and Cognitive Categories", Gospel in Context 1:4 (1978): 24-29.

34 Walaupun sangat berpengaruh di dalam wacana misiologis, perbedaan antara himpunan yang membatasi versus himpunan yang terpusat versi Hiebert tidaklah memadai secara konsep maupun praktis. Himpunan yang terbatas harus memiliki ciri-ciri yang terpusat, dan himpunan yang terpusat harus berjalan di dalam batasan-batasan tertentu. Selain itu, klaim apa pun yang mengatakan bahwa kedua paradigma ini saling terpisah satu dengan yang lainnya atau bahwa yang satu lebih inferior daripada yang lainnya tidak dapat dipertahankan secara Alkitabiah. Charles Van Engen (Mission on the Way: Issues in Mission Theology [Grand Rapids: Baker, 1996], 183) membangun "Paradigma Injil"-nya di sekitar asumsi himpunan terpusat. Dia menyatakan, "Pertanyaan utama bukanlah kepada sistem agama apa seseorang digolongkan. Tetapi, isu pentingnya adalah apa yang menjadi pusat seseorang. Pertanyaan paling hakiki adalah pertanyaan mengenai pemuridan, mengenai kedekatan, atau jarak, seseorang kepada Yesus Tuhan." 
terdiri dari orang-orang percaya yang tetap tinggal di dalam dan mengubah jaringan keluarga mereka sendiri yang sudah ada, mengganggu keluarga dan komunitas mereka sedikit mungkin. Keluarga-keluarga orang percaya ini dan jaringan relasi mereka adalah gambaran lokal yang valid dari Tubuh Kristus." 35 Lewis dan pendukung IM lainnya menganggap struktur-struktur keagamaan yang berbeda bersifat netral, oleh karenanya mereka bicara mengenai Muslim "Mesianik" atau "Alkitabiah", dan "pengikut Kristus yang beragama Hindu". ${ }^{36}$ Oleh karena itu, baik seorang Muslim, Hindu, atau pun Budha, struktur-struktur sosio-agama yang ada seharusnya menjadi ungkapan yang sesuai bagi kepercayaan kepada Yesus. ${ }^{37}$ Lewis memanggil kita untuk memikir kembali kategori-kategori kita dan, tanpa memberikan batasan-batasan kualifikasi, melegitimasi komunitaskomunitas non-Kristen pengikut Yesus ini. Dia bantah Lewis dengan mengatakan bahwa Alkitab memperbolehkan sikap seperti itu terhadap bentuk-bentuk agama ini: "Sama seperti di dalam Perjanjian Baru, Dia [Yesus] sepertinya tidak terlalu peduli terhadap struktur-struktur atau bentuk-bentuk keagamaan yang didirikan di dalam nama-Nya." 38

Lewis menggambarkan orang dalam (insiders) sebagai "orang yang tetap tinggal di dalam dan mentransformasikan"39 jaringan-jaringan sosial ini; akan tetapi, efektivitas dari pengaruh transformasi seperti itu sangat

\footnotetext{
35 Lewis, "Promoting", 76 (penekanan sesuai aslinya).

36 Rick Brown, "Biblical Muslims," IJFM 24:2 (2007): 65-74; John Travis, "Messianic Muslim Followers of Isa," 53-59; Peterson, "Possibility of a 'Hindu Christ-Follower,'" 87-97; http://www.jesusinthequran.org/ (diakses 26 Mei 2012).

37 Lewis bersikeras mempertahankan dua ciri khas IM: "1. Injil mengakar dalam komunitas atau jaringan sosial yang sudah ada, yang menjadi ekspresi utama dari 'gereja' di dalam konteks tersebut. Orang percaya tidaklah dikumpulkan dari berbagi jaringan sosial yang berbeda untuk menciptakan suatu 'gereja'. Struktur sosial paralel yang baru tidak diciptakan atau diajukan. 2. Orang percaya tetap mempertahankan identitas mereka sebagai anggota komunitas sosio-agama mereka dan hidup di bawah ketuhanan Yesus Kristus dan otoritas Alkitab" ("Honoring", 16, penekanan sesuai dengan aslinya).

38 Lewis, "Can the Kingdom", 15.

39 Lewis, "Promoting", 76.
} 
mencurigakan dan sebenarnya tidak dapat diukur secara objektif. ${ }^{40}$ Tetapi yang lebih penting lagi adalah cara bagaimana jaringan-jaringan ini dan kebiasaan mereka dapat "ditransformasi" untuk menyatakan bahwa pemikiran IM memiliki kecenderungan untuk menerima tradisi dan kebiasaan agama-agama lain. Konsep netralitas atas aktivitas agama seperti itu, yang menentukan paradigma IM, harus diuji oleh Alkitab. Karena alasan-alasan yang berbeda, baik pendukung maupun lawan IM menyatakan bahwa sangat penting untuk menjelaskan pemikiran IM. Tanpa mengesampingkan pertanyaan-pertanyaan misi yang vital, seseorang harus menghargai masukan teologis dan eklesiologis dalam pembahasan ini, satu poin yang Lewis sendiri berikan secara jelas adalah: hal yang dipertaruhkan di sini adalah "integritas dari Injil itu sendiri". ${ }^{41}$

Karena pertaruhan yang penting ini, kita harus mempertimbangkan pertanyaan mengenai integritas ini. Apakah "Injil" IM sebagaimana yang dibicarakan oleh Lewis benar-benar menceritakan mengenai Injil Yesus Kristus, Anak dari Allah yang hidup, secara Alkitabiah? Apakah pendekatan IM terhadap Alkitab telah dengan setia memberitakan Yesus Kristus sebagai Tuhan yang telah dibangkitkan, dengan memperhatikan nilai kosmik, penebusan, hermeneutika, eklesiologi, dan misiologi yang seharusnya diberikan kepada-Nya?

\section{Fondasi dari Hermeneutika IM}

Di "Integrity", Lewis membahas prinsip-prinsip utama: isi yang tidak berubah dan lingkup yang tidak berubah dari Injil. Mengenai lingkup injil, Lewis menekankan sifat universal dari kabar baik untuk semua orang.

40 Kesulitan ini diperburuk dengan kerancuan identitas. Apakah orang dalam (insiders) ini adalah orang Muslim? Apakah mereka adalah orang Kristen? Apakah mereka adalah orang Muslim dan Kristen? Apakah yang dimaksud dengan "Muslim Mesianis"?

41 Lewis, "Integrity”, 46. 
Mengenai isi injil, dia menegaskan dengan menggunakan kata-kata yang sesuai dengan amanah Paulus tentang kemurnian Injil (Galatia 1:1-9): kita tidak boleh merusak Injil "dengan menambahkan syarat-syarat tambahan seperti kepatuhan terhadap tradisi-tradisi Kristen." 42 Dengan secara terbuka mengakui kemurnian dan keuniversalan Injil, formulasi awal ini kedengarannya sangat meyakinkan. Pengharapan semacam ini bertumbuh melalui penjelasannya mengenai sejarah Alkitab, dengan melihat Injil sebagai penggenapan Kitab Suci Ibrani:

Karena sunat adalah tanda perjanjian yang Allah lakukan dengan Abraham, dan Pentakosta adalah perayaan bagi pemberian hukum kepada Musa di atas loh-loh batu, maka Injil sebagai perjanjian baru dan kedatangan Roh Kudus di Pentakosta adalah penggenapan, bukan pembatalan dari semua janji-janji Allah di dalam Kitab Suci Ibrani. ${ }^{43}$

Tetapi ketika kita menggali ke dalam struktur formulasi Lewis, kita menemukan beberapa pijakan yang dipakai di dalam paradigma interpretasi yang sangat lemah. Pernyataan mengenai penggenap organik Alkitabiah dinodai dengan bagaimana dia bersikeras menyatakan bahwa sifat keYahudi-an Injil hanyalah persoalan "kerangka religius". Praktik-praktik di dalam Perjanjian Lama bersifat kebudayaan, dan oleh karena itu mereka bukanlah persoalan Injil (spiritual) tetapi persoalan agama (manusia). ${ }^{44}$ Bahkan fakta bahwa "kerangka agama" PL merupakan "pemberian Allah" 45 berarti bahwa isinya, yang mengharuskan praktik-praktik tertentu, hanya diperuntukkan bagi orang Yahudi sebagai satu bangsa, kebudayaan, sekelompok orang. Di dalam zaman PB, isi Injil yang tidak berubah datang terlebih dahulu kepada orang Yahudi di dalam konteks mereka, tetapi konteks

\footnotetext{
42 Ibid., 42.

43 Ibid.

44 Seturut dengan analisis Fuller (lihat catatan 15), bagi Lewis, agama berasal dari sekelompok orang, memberikan definisi kepada konteks mereka, dan berfungsi sebagai ciri khas dari identitas budaya bukan memberikan signifikansi spiritual atau moral.

45 Lewis, "Integrity", 42.
} 
praktik-praktik agama mereka adalah milik mereka secara etnis, dan keYahudi-an dari Injil kehilangan signifikansinya di luar dari catatan sejarah atas masuknya Injil ke dalam komunitas mereka.

Oleh sebab itu, menurut Lewis, "komunitas agama Yahudi" ini hanya merupakan suatu wujud budaya non-teologis di mana beberapa anggota tertentu di abad pertama memasukkan Yesus masuk ke dalam hidup dan bentuk-bentuk keagamaan mereka. Praktik-praktik di dalam komunitas agama ini tidaklah memiliki signifikansi rohani di dalam arti yang paling hakiki dan sepenuhnya terpisah dari substansi Injil yang sesungguhnya. Maka, arti dari Injil melampaui fenomena budaya ini, bukan dengan cara transformasi radikal tetapi suatu interpretasi ulang yang bertahap. Di sinilah struktur pemikirannya yang paling mendasar muncul untuk pertama kalinya - yaitu, komitmen yang mendorong Lewis, selaras dengan McGavran dan Kraf, yang adalah antropologi budaya.

Dengan pola pikir budaya-antropologi seperti ini, maka kesementaraan membuktikan makna suatu kebudayaan dapat berubah; bahwa bentuk-bentuk religius Yahudi telah berakhir menunjukkan bahwa mereka tidak memiliki mandat ilahi yang berotoritas atau, paling tidak, mereka tidak memiliki makna spiritual yang diperlukan dalam kehidupan rohani. Lewis menyatakan bahwa, "Paulus menunjukkan bahwa tradisi religius orang Yahudi yang percaya belum melepaskan mereka dari natur dosa mereka (Efesus 2:3), maupun juga dari perbudakan mereka oleh kekuatan setan (Galatia 4:3)."46 Dia kemudian menyimpulkan, "Tradisi-tradisi ini pun juga tidak akan melepaskan bangsa-bangsa lain dari dosa, hanya akan memimpin kepada suatu perbudakan yang baru." 47 Di permukaan, kalimat ini tampaknya sesuai dengan pemikiran Paulus. Paulus memang memanggil mereka yang percaya kepada Kristus keluar dari ketergantungan kepada

$46 \quad$ Ibid., 45.

47 Ibid. 
aktivitas religius kepada ketergantungan penuh pada Yesus Kristus. Seperti yang Lewis tegaskan kembali, "Perhatian utama Paulus adalah untuk integritas Injil." 48 Tetapi, apa yang dia maksud dengan "tradisi-tradisi agama", integritas Injil, dan ketergantungan kepada Kristus, harus kita bahas lebih lanjut.

Bentuk agama yang utama yang diangkat oleh Lewis adalah sunat. Melalui orientasi kebudayaannya, Lewis bersikeras mengatakan bahwa Paulus "telah mengubah tanda perjanjian dari tanda eksternal (sunat, Kejadian 17:13) menjadi tanda internal". ${ }^{49}$ Tanda eksternal dari perjanjian ini bagi Lewis adalah salah satu dari tradisi-tradisi agama, sehingga tidak memiliki nilai spiritual yang nyata di dalam Perjanjian Lama. Kita segera menghadapi masalah di sini. Kesimpulan ini tidak sesuai dengan penjelasan Alkitab mengenai sunat, 50 dan menentang karakter spiritual dari tanda ini dan cara bagaimana Alkitab (di PL dan PB) menyajikan keselamatan, iman, dan ketaatan. Walaupun sebagian orang di Israel telah memperlakukannya secara salah, tanda ini tidak pernah hanya berfungsi sebagai tanda etnis (Roma 4:11), sehingga interpretasi sunat sebagai suatu hal yang eksternal adalah salah secara moral, bukanlah suatu hal yang netral secara agama. ${ }^{51}$

Pertanyaan-pertanyaan mengenai sunat mengarahkan kita kepada surat-surat Paulus, seperti Roma, Galatia, Filipi, dan Kolose. Kami akan

\footnotetext{
48 Ibid., 46.

49 Ibid., 44.

50 Untuk pembahasan lebih lanjut mengenai karakter biblico-theological dari sunat, lihat John Fesko, Word, Water, and Spirit: A Reformed Perspective on Baptism (Grand Rapids: Reformation Heritage, 2010), dan Meredith Kline, By Oath Consigned: A Reinterpretation of the Covenant Signs of Circumcision and Baptism (Grand Rapids: Eerdmans, 1968).

51 Poin kita dalam artikel ini bukan untuk memaksakan keputusan mengenai baptisan anak (paedo-baptism) atau baptisan dewasa (credo-baptism), melainkan menekankan spiritualitas dari sunat sebagaimana yang dinyatakan oleh PL dan PB. [Catatan editor: Bandingkan artikel David Gibson di terbitan jurnal Themelios ini: "Sacramental Supersessionism Revisited: A Response to Martin Salter on the Relationship between Circumcision and Baptism," tersedia di http://thegospelcoalition.org/themelios/article/sacramental_supersessionism_revisited_a_ response_to_martin_salter_on_t].
} 
membahas Kolose 2:11-12 secara singkat dalam bagian ini. Ada beragam tafsiran mengenai nats di atas, 52 tetapi semua eksegesis yang baik dengan jelas menyatakan bagaimana Paulus memahami signifikansi spiritual dari sunat dan menemukan makna penggenapan teologisnya di dalam penebusan Kristus. Bobot spiritual yang Paulus berikan kepada sunat bukanlah ciptaan PB (Roma 2:28-29; 4:11-12), tetapi merupakan penggenapan PB. Paulus tidak mengganti sunat dari realitas eksternal menjadi realitas internal. Sunat adalah tanda spiritual (Ulangan 10:12-16). Sunat berkenaan dengan perintah kovenan eksplisit yang Allah berikan kepada umat perjanjian-Nya untuk mereka taati (Kejadian 17; Imamat 26:40-42; Roma 2:25-29; Efesus 2:11-14).

Paulus berulang kali dan dengan keras menegur orang-orang yang mencari nilai dan jaminan penebusan di dalam sunat (Galatia 5:2-6), tetapi bahkan di dalam tegurannya, pembahasannya mengenai subjek tersebut bertentangan dengan semua interpretasi budaya mengenai tanda itu sendiri. Sebaliknya, walaupun sunat bukan merupakan tujuan di dalam dirinya sendiri maupun sarana untuk mendapatkan tempat di hadapan Allah (band. Galatia 6:15), Rasul Paulus membangun signifikansi spiritual yang organiknya dari seluruh PL di atasnya, menyatakan bagaimana tanda ini mencapai puncaknya di dalam pribadi dan karya dari Yesus Kristus.

Sebagai kesimpulan, sunat fisik dimandatkan hanya pada zaman PL sehingga tidak menjadikan arti dari tanda tersebut bersifat kebudayaan atau hanya tradisi agama; kesimpulan semacam ini adalah suatu kesimpulan naif non sequitur. Perubahan di PB, di dalam memberhentikan keharusan sunat, bukanlah karena nilai dari sunat yang dapat dinegosiasikan secara budaya,

52 Walaupun bukanlah pandangan umum yang mayoritas, penulis artikel ini setuju dengan tafsiran O'Brien bahwa sunat Kristus adalah penghakiman eskatologis yang ditanggung dalam tubuh-Nya sendiri (Kol. 2:11-12). Peter T. O’Brien, Collosians, Philemon (WBC; Waco: Word, 1982), 117-18. 
tetapi karena berakhirnya fungsi dari perjanjian sebelumnya (Efesus 2:12). Maka dari itu, transisi dari PL kepada PB menyatakan pergerakan dari janji spiritual kepada penggenapan spiritual, bukan bentuk-bentuk kebudayaan yang diterapkan secara kreatif atau secara interpretif oleh para rasul. ${ }^{53}$

Pembahasan Lewis mengenai sunat yang berpusat kepada kebudayaan (culture-centric) membongkar struktur landasan di dalam metode penafsirannya. Dengan menetapkan bahwa pemberhentian sunat adalah bukti bahwa sunat dapat dinegosiasikan secara spiritual menyatakan ketergantungan epistemologi kepada budaya sebagai kekuatan penentu dalam menafsirkan Alkitab. Keutamaan budaya di praktik Yahudi menghasilkan kesimpulan bahwa praktik agama lainnya juga bersifat netral dalam hal budaya, oleh karenanya, bukan merupakan persoalan penting bagi Injil. Bahwa kisi-kisi kebudayaan yang sangat menentukan ini menjadi pendorong bagi Lewis dalam menafsirkan IM menjadi suatu hal yang jelas ketika kita melihat bagaimana dia menganalisis bagian-bagian Alkitab lainnya melalui paradigmanya mengenai sunat. ${ }^{54}$

\section{Yohanes 4 dan Samaritanisme}

Dengan menggunakan teks yang sering dirujuk oleh para pendukung IM, Lewis berpendapat bahwa apa yang dilakukan Yesus terhadap perempuan Samaria (Yohanes 4) menyingkapkan berita Injil yang

\footnotetext{
53 John Murray secara bijak mengingatkan kita, “Pengetahuan kita mengenai Alkitab, kalau itu benar-benar memadai, harus merupakan pengetahuan mengenai Alkitab sebagaimana adanya ia, dan harus mencerminkan ... karakter organiknya. . . Kita harus mengerti bahwa seluruh Alkitab berdiri bersama dan hubungan organik berjalan melalui seluruh Alkitab menghubungkan satu bagian dengan semua bagian lainnya dan setiap kebenaran dengan semua kebenaran lainnya" ("The Study of the Bible", in Collected Writings, vol. 1: The Claims of Truth [Edinburgh: Banner of Truth, 1976], 5).

54 Walaupun Lewis memberikan komentar khususnya atas Yoh. 4 dan Kis. 15, teks favorit IM lainnya termasuk Bil. 22-24; 2Raj. 5; 1Kor. 7; 1Kor. 9; dan kitab Yunus. Lihat Bill Nikides, "The Insider Story: Theology", di Chrislam, 12-22; idem, "Lost in Translation: Insider Movements and Biblical Interpretation", di Chrislam, 44-61; Tennet, "Followers of Jesus", 105-9.
} 
melampaui agama Yahudi. ${ }^{55}$ Menurut Lewis, "Yesus telah memberikan kebebasan untuk beribadah 'di dalam roh dan kebenaran' kepada orang-orang Samaria yang percaya tanpa mengharuskan mereka untuk menjadi pemeluk agama baru (proselytes) atau masuk ke dalam sinagoge Yahudi." 56 Kesimpulan ini benar, tetapi bukan seperti yang Lewis simpulkan dari bagian ini. Yesus bukan sedang memberitakan ambivalensi budaya, yakni bahwa tradisi/kebiasaan Yahudi dapat diterima dan tradisi/kebiasaan Samaria juga dapat diterima. Dia tidak memberitakan ambivalensi mengenai identitas sosio-agama. Tetapi Dia memberitakan bahwa Dia menggenapi wahyu yang datang melalui Abraham dan Musa dan bahwa Dia telah datang untuk meresmikan zaman baru yang dijanjikan itu.

Pengertian sejarah peralihan (transisional) pada bagian ini sangatlah jelas: "Percayalah kepada-Ku, hai perempuan, saatnya akan tiba, bahwa kamu akan menyembah Bapa bukan di gunung ini dan bukan di Yerusalem"(Yohanes 4:21). ${ }^{57}$ Berita Kristus mengenai ibadah "dalam roh dan kebenaran" sarat dengan signifikansi temporal - atau lebih baik, eskatologikal.58 Partikularitas ke-Yahudi-an-Nya mendukung poin historis dan eskatologis ini. Ketika Yesus berkata, "keselamatan datang dari bangsa Yahudi" (Yohanes 4:22), Dia sedang menyatakan cakupan yang luas mengenai signifikansi teologis-Nya di atas dasar identitas-Nya yang sempit sebagai seorang Yahudi. Dengan kata lain, apa yang menjadikan keselamatan-Nya berkhasiat bagi wanita Samaria ini adalah identitas inkarnasi-Nya yang menggenapkan PL sebagai Mesias Yahudi yang

55 Lihat Lewis, "Integrity", 42. Lewis juga membicarakan Yoh. 4 dan Kis. 15 di "Honoring", 17-18.

56 Lewis, "Integrity", 42.

57 Kutipan-kutipan Alkitab diambil dari Alkitab, Alkitab Terjemahan Baru, hak cipta @ 1997 oleh Lembaga Alkitab Indonesia.

58 Hal yang memperkuat kerangka eskatologis di bagian ini yang sudah eksplisit adalah penekanan pada kata Roh. Lihat, D. A. Carson, The Gospel according to John (Leicester: IVP, 1991), 224-26. 
dijanjikan ("Akulah Dia, yang sedang berkata-kata dengan engkau", Yohanes 4:26) masuk ke dalam sejarah di Palestina. Nilai keselamatan-Nya terletak tepatnya pada penggenapan wahyu khusus, wahyu yang bergerak dari partikularitas (Yahudi) kepada universalitas (orang Samaria, bangsabangsa lain, dan sebagainya) sesuai dengan perjanjian dengan Abraham (Kejadian 12:1-3). Pendek kata, relevansi-Nya secara universal berasal dari partikularitas eskatologi-Nya.

Sarat dengan signifikansi teologis yang menentukan, perintah Yesus kepada wanita Samaria ini tidak dapat dimengerti sebagai persetujuan terhadap netralitas budaya! Melainkan, menyatakan identitas diri-Nya sebagai penggenapan sejati dari wahyu Alkitab dan sebagai Mesias eskatologis, Yesus memanggil dia kepada suatu kepatuhan baru yang radikal, sesuai dengan bobot teologis dari momen historis ini. Identitas ontologis dan eskatologis-Nya mengisyaratkan suatu pengertian dan praktik ibadah yang berbeda secara kategori - ibadah di dalam "roh dan kebenaran" yang didefinisikan oleh iman di dalam Anak Allah, bukan oleh Samarianisme. Tentunya, mengikuti Yesus tidak menghilangkan legitimasi identitas budaya perempuan Samaria ini, tetapi mengikuti secara setia juga tidak dapat dimengerti secara tepat dengan dia memberikan afirmasi kepada identitas dan praktik-praktik agamanya sedemikian sehingga ibadah di dalam "roh dan kebenaran" dimengerti secara budaya bukan ditransformasi secara eskatologi. Interpretasi yang tepat terhadap kejadian ini menuntut kita untuk membawa semua dimensi Samarianisme di bawah otoritas teologis dari identitas Kristus, daripada menyerahkan otoritas Kristus di bawah hegemoni budaya atau agama Samaria. Paling tidak, konstruksi dari Lewis gagal memperhitungkan aspek eskatologi yang terpancar dari teks tersebut, oleh karenanya, memudarkan arti utamanya dan bersalah di dalam menggantikan substansi teologi dengan keanekaragaman budaya. 


\section{Kisah Para Rasul 15 dan Sejarah Penebusan}

Setelah memahami kemiripan budaya/agama tertentu antara Samaria dan Yahudi, Lewis berpaling kepada apa yang dia anggap sebagai kasus bangsa-bangsa kafir yang lain yang lebih sulit, kebudayaan dan agama mereka. Dengan menyimpulkan analisisnya atas perkembangan Injil di abad pertama, dia menanyakan dua pertanyaan formatif:

Apakah berita Injil membawa anugerah hanya kepada mereka yang bergabung dengan keluarga orang beriman (orang beriman yang disunat dan menjalankan hukum Musa) atau dapatkah Injil membawa keselamatan untuk semua orang, tanpa memperhatikan konteks sosial dan agama mereka? ...

Apakah berita mengenai Yesus Kristus hanya memiliki kuasa untuk menyelamatkan orang-orang yang menerima kerangka agama di mana Kristus telah berinkarnasi, atau mungkinkah Injil menyelamatkan mereka yang berada di konteks yang asing juga? ${ }^{59}$

Pada awalnya, pertanyaan ini kelihatannya cukup sepele. Lagi pula, siapa yang akan menyangkal bahwa Injil tidak mengharuskan bangsabangsa lain untuk menjadi Yahudi? Siapa yang akan menyangkal bahwa Injil bertolak belakang dengan agama yang didasarkan perbuatan baik (worksreligion)? Dengan beralih kepada yang dicatat di Kisah 15, Lewis menunjukkan apa yang dia benar-benar maksudkan dengan pertanyaannya. Dia menggambarkan orang Yahudi yang setia di Perjanjian Lama sebagai mereka yang mempraktikkan "tradisi-tradisi agama", 60 dan kemudian menyimpulkan bahwa khotbah Petrus di Kisah 15 dimaksudkan untuk membela "kuasa Injil untuk menyelamatkan orang percaya yang memelihara budaya dan identitas bangsa non-Yahudi mereka".61 Dengan bergerak langsung kepada Rasul Paulus, dia menyimpulkan bahwa Paulus juga berpendapat "berulang kali bahwa Injil harus masuk kepada kumpulan

59 Lewis, "Integrity", 43.

60 Ibid.

61 Ibid. 
orang-orang bangsa lain tanpa dirintangi oleh tuntutan agama yang bersifat eksternal".62 Maka Lewis menyimpulkan bahwa untuk menjadikan praktikpraktik agama menjadi persoalan bagi Injil akan merusak kemurnian Injil. Selain itu, tradisi agama orang Yahudi telah membuktikan bahwa mereka tidak mungkin menyelamatkan manusia, ${ }^{63}$ dan "Injil itu sendiri yang adalah kuasa yang mentransformasi hidup orang percaya",64 bukan agamanya. Oleh karena itu, menurut Lewis, praktik-praktik agama seseorang bukanlah bagian dari Injil, karena Injil melampaui - atau lebih baik, bukanlah menjadi perhatian utamanya - identitas dan praktik-praktik agama seseorang.

Bungkusan budaya dari hubungan Yahudi dan bangsa-bangsa lain di abad pertama ini terurai secara cepat. Menurut Alkitab, iman yang sejati memperkenalkan seorang percaya kepada identitas yang baru di dalam Yesus Kristus (Kolose 3:1-17) dan kepada suatu identitas kekeluargaan yang baru di dalam persekutuan dengan orang-orang lain yang secara khas dipanggil sebagai anak-anak Allah melalui iman (Roma 8:16-17; 1 Korintus 12:12-31). Ketuhanan Kristus melampaui agama dan budaya, bukan mengabaikannya, tetapi ia menentang praktik-praktik kafir dan memanggil orang-orang Yahudi dan kafir yang telah ditebus kepada komunitas Alkitabiah dan yang dibentuk oleh Kristus, dengan bentuk-bentuk etika dan keagamaan yang telah diwahyukan secara ilahi. Iman sebagai karunia ilahi menghidupkan orang mati dan hati yang tidak percaya (Efesus 2:1-10) dan memerangi semua praktik-praktik pemberontakan moral dan agama (Yakobus 2:14-26; 1 Korintus 6:1-20) - yang merupakan distorsi atas agama yang diwahyukan atau agama palsu yang diciptakan oleh manusia (atau setan). Komitmen dan praktik-praktik pokok seseorang mendapatkan pemahaman dan perombakan ulang sesuai dengan Injil Yesus Kristus

$\begin{array}{ll}62 & \text { Ibid., } 44 . \\ 63 & \text { Ibid., } 45 . \\ 64 & \text { Ibid. }\end{array}$ 
(Ibrani 10:19-39; 1 Korintus 15:1-58).

Pendukung IM yang terbaik pasti setuju dengan prinsip dari konfrontasi Injil dengan orang yang tidak percaya, tetapi komitmen IM terhadap otonomi orang-orang di budaya agama lain, apa yang diperangi oleh Injil dan bagaimana hal tersebut dilakukan menjadi tidak terbatas dan tidak memadai. Ketajaman pengertian mengenai pengaruh Injil yang berotoritas terhadap kebudayaan dan praktik-praktik agama terhalangi ketika paradigma interpretasi seseorang adalah kebudayaan dan bukan penebusan-historis (redemptive-historical). Eksposisi Lewis di bagian ini dirugikan karena pengkaburan ini, ketika dia menilai situasi tersebut melalui paradigma kebudayaan yang lemah daripada paradigma teologis/eskatologis yang menentukan. Kita akan membahas contoh-contoh yang lebih spesifik mengenai kuasa dan panggilan Injil nanti. Tetapi untuk saat ini, kita harus menyatakan bahwa untuk dapat mengerti mengenai konteks Yahudi dan orang kafir, bentuk wahyu Alkitab yang kaya secara organik dan teologi tidak akan dihancurkan di bawah analisis kebudayaan yang memberikan afirmasi kepada identitas dan praktik agama tanpa perbedaan atau yang meminimalkan antitesis spiritual antara mereka yang percaya dan yang tidak percaya. ${ }^{65}$

65 Kerancuan dan pengurangan seperti itu telah menjadi hal yang umum di banyak argumen misiologis. Contohnya, Van Engen (Mission on the Way, 183-87) mengajukan tiga implikasi misi dari "Paradigma Penginjil"-nya, yaitu: (1) partikularisme iman, (2) pluralisme kebudayaan, dan (3) inklusivisme eklesiologis. Walaupun kita dapat menghargai pernyataan yang jelas mengenai keselamatan hanya di dalam Kristus, model ini gagal di dalam mempertimbangkan pertanyaan-pertanyaan epistemologi yang kritis, menutupi hubungan antara iman dan kebudayaan, dan melalui definisi gereja yang dikurangi ini, secara efektif menjauhkan iman pribadi dari apa yang diajarkan oleh Alkitab mengenai eklesiologi. "Sebagaimana yang diberitakan oleh Paulus di Roma, dan kita melihat dicontohkan di Kisah Para Rasul, mengaku dengan mulut dan percaya di dalam hati bahwa Yesus adalah Tuhan-sebagaimana yang seharusnya. Tidak ada hal lainnya yang lebih penting lagi. Yang lainnya dapat dinegosiasikan" (184). 
Sebelum kita melanjutkan pembahasan mengenai argumen Lewis, kita perlu membicarakan satu hal mengenai interpretasi Alkitabiah. Hal yang penting untuk hermeneutika Alkitab adalah natur organik dari peristiwa-peristiwa penebusan yang ditandai, dinantikan, dan digenapi. Dari perspektif penebusan-historis Alkitab, Yesus adalah perwujudan dari janji Alkitab (Yahudi), dan dorongan eskatologi di Yohanes 4 memang mengkarakterisasikan wahyu Alkitab. Oleh karena itu, ke-Yahudi-an Yesus penting untuk alasan-alasan teologis, karena kepada orang Yahudilah tiba wahyu ilahi dan janji Mesias (Kejadian 12). Selain itu, penggenapan Kristus atas perjanjian dengan Abraham (Kejadian 12), juga relevan bagi bangsa kafir sebagaimana hal tersebut relevan bagi orang Yahudi; Abraham dipanggil sebagai bapa semua yang percaya - Yahudi dan kafir (Roma 4:1112; Galatia 3:7-9, 27-29). Walaupun wahyu ilahi datang melalui orang Yahudi, beritanya yang berotoritas dan bersifat penebusan menjadi tanda utama dari zaman (Ibrani 1:1-4) ketika Yesus Kristus Sang Tokoh Utama dari semua sejarah membawa wahyu yang sedang disingkapkan itu kepada titik akhirnya melalui kehidupan, kematian, kebangkitan, dan kenaikan-Nya. Wahyu PB yang spiritual dan dinamis itu didasarkan pada wahyu PL yang hidup, namun bersifat antisipasi dalam PL. Keresahan (antisipasi) spiritual di dalam wahyu PL memang terkandung di dalam wahyu itu sendiri.66

Sebagaimana yang dipaparkan oleh para rasul, abad pertama Masehi adalah suatu periode sejarah penebusan yang unik dan tidak terulang lagi. Ini adalah masa transisi; pekerjaan Yesus Kristus meresmikan zaman baru yang dijanjikan (Kisah Para Rasul 2:17; Ibrani 1:1-2; 9:26; band. Matius 12:28; Paulus menggunakan kata "buah pertama” di Roma 8 dan 1 Korintus 15). Seluruh PB secara organik terhubung dengan PL, sebagaimana PB menyatakan dengan klimaks Anak Allah yang berinkarnasi sebagai

66 David B. Garner, "Did God Really Say?" di Did God Really Say? Affirming the Truthfulness and Trustworthiness of Scripture (ed. David B. Garner; Phillipsburg: Presbyterian\& Reformed, 2012), 154-59. 
substansi dari semua antisipasi PL (lihat mis. Lukas 24:13-49; Roma 1:1-7; Ibrani 1:1-4; Yohanes 5:39-47). Oleh karena itu, haruslah dimengerti bahwa peristiwa-peristiwa utama yang tersirat di dalam PB itu sendiri kehidupan, kematian, dan kebangkitan Yesus Kristus - pada dasarnya bersifat eskatologikal.67 Maka, Kisah Para Rasul dan surat-surat di PB harus dilihat melalui peristiwa-peristiwa historis dan kristologis ini. Sebagaimana yang Paulus katakan, seluruh pelayanannya berpusat kepada kehidupan, kematian, dan kebangkitan Kristus yang menggenapi Alkitab (1 Korintus 2:2; 15:1-3); pribadi Kristus dan karya-Nya sepenuhnya membentuk interpretasinya terhadap Alkitab (2 Korintus 1:20); dan kemenangan historis Kristus mendefinisikan metode proklamasinya (Efesus 3:8-13). ${ }^{68}$ Presuposisi interpretasi dari pelayanan rasuli adalah penggenapan penebusan di dalam Yesus Kristus; pusat eskatologi ini membentuk semua refleksi atas penebusan yang digenapi, diterapkan, dan diproklamasikan. ${ }^{69}$

Di dalam periode transisi historis yang unik di dalam Kisah Para Rasul ini, gereja bertumbuh di dalam pengertiannya mengenai makna kosmik yang penting dari pekerjaan Yesus Kristus ini dan pencurahan Roh Kudus yang belum pernah terjadi sebelumnya. Walaupun kebudayaan pasti merasakan getaran pada titik historis penting ini, ini bukanlah hanya periode pergolakan kebudayaan. Ini adalah pertama-tama periode

67 Sering kali eskatologi diturunkan derajatnya secara ceroboh kepada diagram dan grafik spekulatif dengan menunjukkan kronologi dari peristiwa di masa depan. Alkitab menyajikan eskatologi secara jelas di dalam pengertian yang berbeda, menghubungkan PL dan PB secara historico-genetic, sesuai dengan interpretasi dua-zaman (band. Geerhardus Vos, The Pauline Eschatology; repr., Phillipsburg: Presbyterian \& Reformed, 1994). Pengharapan terhadap kedatangan Mesias pada Akhir Zaman menjadi ciri khas masa PL. PB menggambarkan Yesus Kristus sebagai penggenapan pengharapan tersebut dan menjelaskan kedatangan pertama-Nya dari sisi signifikasi waktunya (lihat, mis. Ibr. 1:1-2). Pendek kata, Yesus memulai Akhir Zaman; dia meresmikan eskatologi. Bicara secara historis dan eskatologis, kita bukan sedang menantikan Akhir Zaman; sejak abad pertama Masehi, kita sudah berada di dalamnya. 68 Lihat, misalnya, Dennis E. Johnson, Him We Proclaim: Preaching Christ from All the Scriptures (Phillipsburg: Presbyterian \& Reformed, 2007), 198-238.

69 Lihat John Murray, Redemption Accomplished and Applied (Grand Rapids: Eerdmans, 1955). 
pergolakan teologis di mana bentuk-bentuk ibadah PL diganti dengan bentuk-bentuk substansi Yesus Kristus sendiri. Para rasul menghadapi tantangan untuk memimpin gereja yang bergerak dari bentuk-bentuk spiritual tipological (PL) menuju pengertian dan aplikasi dari realitas yang dilambangkan (PB). Sekali lagi, yang utama dari transisi ini bukanlah masalah adaptasi kebudayaan tetapi realisasi teologi yang organik. Bayangbayang Perjanjian Lama telah membuka jalan bagi cahaya kristologi yang mulia. Alasan para rasul melakukan hal-hal di Kisah 15 adalah ketika mereka melihat "gerakan menuju Kristus di antara orang-orang Yunani berasal dari Allah dan orang-orang Yunani Kristen tidak seharusnya dipaksa untuk mengadopsi tradisi-tradisi agama dari gereja di Yerusalem" 70 bukanlah sesuatu netralitas kebudayaan. Tetapi, mereka bertindak demikian karena masa transisi yang telah diresmikan oleh Yesus Kristus Anak Allah telah disaksikan dengan pencurahan Roh-Nya. Pekerjaan Kristus, sebagai penggenapan dari janji yang dibuat kepada Abram (Kejadian 12), menandai permulaan zaman yang baru di dalam Injil. Realitas historis dan teologis ini mengubah segalanya.

\section{Eskatologi dan Identitas di dalam Kristus}

Sebagai kesimpulan, argumen di dalam Kisah 15 sudah pasti bukanlah pembelaan atas "kuasa Injil yang menyelamatkan semua yang percaya yang tetap memelihara identitas dan budaya kafir mereka". ${ }^{71}$ Kesimpulan ini mengkhianati interpretasi atas karya Yesus Kristus yang reduksionis dan hambar secara teologi! Praktik-praktik orang Yahudi di Perjanjian Lama telah diberikan secara ilahi, sehingga memiliki signifikansi spiritual yang nyata, suatu signifikansi yang memuncak pada karya Yesus Kristus satu-kali-untuk-selamanya. Iman PL di dalam bentuk yang lama

\footnotetext{
70 Lewis, "Integrity", 44.

71 Ibid., 43.
} 
benar-benar sudah berakhir; iman tersebut sudah mencapai penggenapan di dalam Yesus Kristus, Anak Allah. Maka karena Kristus, kembali kepada agama Yahudi di dalam bentuk kovenan lamanya adalah suatu hal yang sudah tidak perlu lagi. ${ }^{72}$ Berhentinya praktik Perjanjian Lama seperti itu menandakan kesetiaan Allah kepada janji-janji spiritual-Nya (Kejadian 12; Galatia 3:8)! Tentu saja, kita tidak menemukan para rasul memerintahkan pendengarnya untuk menyangkal identitas budaya mereka secara diamdiam; tetapi kita melihat mereka secara konsisten memanggil pendengar mereka kepada iman yang melahirkan ketaatan (Roma 1:7; 16:25), di mana persatuan mereka dengan Yesus Kristus sekarang secara komprehensif telah mendefinisikan identitas mereka, dan karena identitas ini, mereka dipanggil untuk menyerahkan seluruh hidup mereka, kebiasaan-kebiasaan budaya, dan praktik-praktik agama mereka kepada otoritas eksplisit Yesus Kristus. Solidaritas iman dan pengakuan di dalam perbedaan etnis merupakan wujud dari kekayaan umat Allah yang eskatologis (Ibrani 2:10-18; Wahyu $7: 9-12) \cdot{ }^{73}$

72 Petunjuk apostolik yang terisolir (mis. 1Kor. 7) mengenai keberlanjutan sunat seharusnya dimengerti menurut abad pertama yang merupakan masa yang bersifat transisional. "Satusatunya tanda perbedaan sosiologis yang pada awalnya memiliki signifikansi agama (religius) tetapi sudah tidak lagi memilikinya saat ini - sunat" (Gordon D. Fee, The First Epistle to the Corinthians [NICNT; Grand Rapids: Eerdmans, 1987], 311).

73 Walaupun terus menerus mendorong kesatuan tubuh (di dalam ketaatan dan identitas spiritual), Paulus tidak menolak adanya perbedaan antara orang Yahudi dan bangsa-bangsa lain (Gal. 2:15). Bahkan, di 1Kor. 7:17-24 (band. Lewis, "Integrity", 46), dia mendorong orangorang Yahudi dan bangsa-bangsa lain yang hidup pada abad pertama untuk mengejar ketaatan pada Kovenan Baru, tanpa memedulikan status apakah mereka disunat atau tidak - suatu persoalan mengenai ketaatan yang sangat penting di bawah Perjanjian Lama (band. Gal. 2:3). Di bagian ini Paulus membuktikan secara praktis pemahamannya mengenai bagaimana zaman eskatologi telah mengakhiri ketaatan spiritual dalam tradisi sunat. "Apa yang menjadi perhatian Paulus ... bukan supaya mereka mempertahankan kondisi sosial mereka pada saat itu, melainkan supaya mereka mengenalinya sebagai kondisi yang benar di mana mereka menghidupi panggilan Tuhan. ... Oleh karena itu dia memberitahukan mereka bahwa berada di dalam Kristus tidak meniadakan situasi mereka pada saat itu; tetapi dia juga tidak sedang mengatakan bahwa situasi mereka mengabsolutkan keberadaan mereka di dalam Kristus. ... Injil secara absolut melampaui, dan menghapuskan secara keseluruhan, semua perbedaan 
Tetapi sama seperti apa yang dia lakukan terhadap Yesus dan perempuan Samaria, Lewis menempatkan konteks kebudayaan di Kisah 15 pada posisi yang tertinggi, sehingga paradigma hermeneutikanya memudarkan fakta penebusan-historis (redemptive-historical). Menurut skema IM versi Lewis yang meninggikan kebudayaan sebagai suatu hal yang utama dan menetralisasikan signifikansi spiritual dari agama, keselamatan di dalam Kristus tidak menyelamatkan seseorang dari agama yang salah, tetapi di dalam agama yang salah. Kesalahan kristologi ini menyatakan dirinya bukan hanya melalui cara Lewis menginterpretasikan Alkitab kuno, tetapi juga melalui cara di mana dia membahas ajaran Alkitab untuk praktik kontemporer IM di berbagai macam kelompok masyarakat di seluruh dunia.

\section{Hermeneutika IM: Kehidupan Kristen, Gereja, dan Misi}

Untuk membahas konteks misi modern, Lewis memikirkan kembali penafsirannya mengenai relasi Yahudi-kafir. Dia mengatakan,

Adalah lebih tepat untuk mengetahui bahwa pada abad pertama paling sedikit ada dua agama yang didasarkan pada Yesus Kristus tetapi yang berbeda secara radikal. Ada versi Yahudi yang menuntut hidup menurut Hukum-hukum Musa dan ritual hari-hari suci Yahudi, dan ada versi YunaniRomawi, yang mengubah hati-hati para pecinta filsafat, dan yang menjelajahi nuansa Trinitas dan inkarnasi. ${ }^{74}$

\footnotetext{
sosial. Di dalam Kristus, orang Yahudi dan Yunani bersatu, hamba atau pun orang yang merdeka, menjadi satu tubuh" (Fee, First Epistle to the Corinthians, 309, 311-12). Walaupun pendukung IM berusaha untuk menemukan paralel kontemporer dalam Islam, Jay Smith menunjukkan kesalahan dari paralel tersebut: "Masalah dari berbicara seperti atau tetap tinggal di dalam Islam adalah bahwa Islam adalah sebuah agama dan kebudayaan. Tinggal di dalam Islam berarti mengambil semua konotasi agama, dan juga kekuatan spiritualnya. Di dalam ayat-ayat ini [1Kor. 7:17-24] Paulus tidak menyarankan orang-orang bangsa lain untuk tinggal sebagai penyembah kafir di dalam tempat-tempat ibadah lokal mereka" (Jay Smith, "An Assesment of IM's Principle Paradigms", di Chrislam, 286). Band. Tennent, "Follower of Jesus", 107.

74 Lewis, "Integrity", 45.
} 
Dengan menggunakan analisis kuno ini, Lewis mengatakan bahwa kita harus mengetahui bahwa "Paulus sedang menetapkan satu pola untuk bagaimana Injil dapat menyusup masuk ke kebudayaan yang berbeda secara radikal."75 Di samping ketidakakuratan pernyataan "kebudayaan [Yahudi dan kafir] yang berbeda secara radikal" 76 yang sebenarnya tidak benar ditinjau dari segi sejarah, pernyataan yang mengejutkan ini dan pernyataan lainnya yang memberikan dukungan perlu dipertimbangkan lebih lanjut. Sebagaimana yang dijanjikan oleh Higgins, memang benar bahwa IM memaksakan "pimpinan-pimpinan gereja untuk menilai kembali praktik dan doktrin gereja"77 sehingga konklusi Lewis memberikan pernyataan yang memformulasikan dan merelativitaskan iman dan kesetiaan. Kami akan membahas tiga aplikasi dari hermeneutika IM yang saling berkaitan untuk praktik dan doktrin pada masa kini.

\section{Praktik Agama yang Direlativitaskan}

Secara sangat jelas, pernyataan rangkuman dari Lewis mengulangi kembali pandangan IM mengenai sifat relatif dari kebudayaan dan agama. Menurut pemikiran IM, orang-orang Yahudi mengambil tradisi kuno mereka dan menambahkan arti-arti "Injil" baru; bangsa-bangsa lain mengambil unsur agama mereka sendiri dan menambahkan kepadanya artiarti yang baru, mendirikan "Injil” yang dipraktikkan sesuai dengan agama

\footnotetext{
$75 \quad$ Ibid., 47.

76 Perbedaan kebudayaan yang dibahas dalam tulisan ini tidak dapat bertahan menghadapi analisis ilmiah mengenai dunia Yahudi Helenis di abad pertama. Lihat, misalnya, Martin Hengel, Jews, Greeks and Barbarians: Aspects of Hellenization of Judaism in the Pre-Christian Period (terj. John Bowden; Philadelphia: Fortress, 1980); James D. Newsome, Greeks, Romans, Jews: Currents of Culture and Belief in the New Testament World (Philadelphia: Trinity Press International, 1992). Meskipun demikian, seperti yang dipertanyakan oleh Louis Feldman, tesis Helenisasi Hengel terlalu dipaksakan, sejarah menolak adanya perbedaan radikal antara kebudayaan Yahudi dan kebudayaan kafir (Louis H. Feldman, Judaism and Hellenism Reconsidered [JSJSup 107; Leiden: Brill, 2006]).

77 Higgins, "Devotes", 155.
} 
dan kebudayaan mereka. Karena PL datang kepada orang Yahudi di dalam konteks kebudayaan mereka, kita harus menafsirkan hal tersebut berdasarkan konteks manusia. Oleh karena itu, melihat PL di dalam penggenapan $\mathrm{PB}$ adalah hal yang penting menurut kebudayaan; penafsiran semacam ini baik untuk orang Yahudi tetapi bukan keharusan bagi bangsabangsa lain. Bahkan perintah-perintah PB harus dibaca melalui lensa kebudayaan yang diberikan oleh hermeneutika IM.78 Ironisnya, pemikiran Lewis mengenai kekuatan Injil yang tak berubah dan transenden mengaburkan fakta bahwa Injil versi Lewis berubah sesuai dengan kebudayaan di mana ia berada; sifat transendennya berubah menjadi bersifat sementara, kekuatannya menjadi lemah. Penerapan Injil semacam ini disesuaikan menurut norma normans (norming norm) dari kebudayaan agama.

Penjabaran atas praktik religius dari IM ini - baik Alkitabiah atau di luar Alkitab - membawa Lewis ke dua arah. Di satu sisi, mengenai orangorang Yahudi, hal tersebut merelativitaskan penggenapan Injil terhadap janji-janji PL. Dengan memaksakan praktik-praktik Perjanjian Lama sebagai hal-hal yang non-spiritual dan non-teologis, Lewis menjadikan penafsiran PB mengenai praktik-praktik PL ini hanya diperuntukkan bagi orang Yahudi yang percaya. Serupa dengan ini, penentuan budaya ini membantu perubahan praktik agama kafir menjadi hal-hal yang netral secara spiritual dan dapat dinegosiasikan. Meskipun dia tidak menganjurkan secara eksplisit tentang praktik-praktik agama spesifik yang mana yang perlu dipelihara oleh orang-orang dari bangsa lain di abad pertama ini, melalui ekstrapolasinya terhadap implikasi kontemporer, kita dapat melihat dengan tanpa keraguan cakupan dari relativisme agama di sini. Orang Muslim tetap menjadi Muslim, orang Budha tetap menjadi Budha, dan orang Hindu tetap menjadi Hindu. Mengapa? Karena "keluarga-keluarga dan komunitas-

78 Lewis, "Integrity", 45. 
komunitas ini telah mengklaim mengetahui dan tunduk kepada Yesus sebagai Tuhan dan Juru Selamat" walaupun hidup "di tengah-tengah kebudayaan yang mirip seperti panteon di dunia Yunani-Romawi penyembah berhala" dan "tetap berada sebagai anggota komunitaskomunitas mereka, termasuk kebanyakan aspek budaya agama mereka". ${ }^{79}$

Lewis memang benar dalam satu hal penting: pengikut Kristus sering kali harus tetap tinggal di dalam kebudayaan mereka, tempat kerja mereka, dan jaringan kekeluargaan mereka, menjadi garam dan terang (Matius 5:1316). Tetapi paradigma IM memperluas batasan dari tetap-tinggal (remaining) dan tetap-memelihara (retaining) secara ilegal, dan hal tersebut tidak bisa dihindari telah melemahkan otoritas Injil. Dengan mengajukan Injil sesuai dengan batasan kebudayaan, hegemoni kebudayaan merelativisasi otoritas Injil. Di dalam hal ini, Lewis menekankan, "tidak seorang pun yang harus memandang iman kepada Kristus di satu agama lebih tinggi daripada di agama lainnya." 80 Bagi Lewis, praktik keagamaan orang Muslim yang tetap menjadi Muslim, orang Budha yang tetap menjadi Budha, atau orang Hindu yang tetap menjadi Hindu bukan saja baik; hal itu adalah satu-satunya cara di mana integritas dari Injil dipelihara. Injil yang tidak berubah, menurut Lewis, adalah Injil himpunan-terpusat (centered-set gospel), yang tidak dicampuradukkan dengan batasan-batasan dari identitas dan aktivitas agama yang seragam. Tetapi hal ini tidak mungkin terjadi. Harga yang harus dibayar terlalu besar. Ketika antropologi kebudayaan menentukan hermeneutika, kebudayaan dan iman mengalami penggabungan yang tidak Alkitabiah, antitesis antara kepercayaan dan ketidakpercayaan dilemahkan, dan garis antara praktik orang percaya dan orang tidak percaya memasuki kabut tebal yang tidak dapat ditembus.

79 Ibid., 41.

$80 \quad$ Ibid., 46. 
Tentu saja Lewis sendiri melihat pemikirannya mengenai poin-poin epistemologis dan metodologis ini sebagai hal yang Alkitabiah, tetapi tanpa disadari penilaiannya mengenai otoritas Alkitab telah dipengaruhi oleh konsep keberagaman kebudayaan Fuller yang kuat: “Hari ini, orang-orang dari berbagai macam kebudayaan yang berbeda ... mengklaim hak Alkitabiah mereka untuk menghidupi iman mereka melalui cara-cara yang berbeda, didasarkan pada Alkitab sebagai otoritas tertinggi." 81 Menurut pemikiran Lewis, otoritas Alkitab baru berfungsi ketika hak pengambilan keputusan mengenai ketaatan Injil berada di tangan sekelompok orang dan bahkan di tangan perorangan.

Persoalan mengenai praktik gerejawi langsung muncul ke permukaan. Walaupun Lewis tidak mempertanyakan isu baptisan per se, pendekatan hermeneutikanya menimbulkan pertanyaan mengenai keharusan baptisan sebagai bentuk ketaatan orang-orang dalam (insider) ini. Bahkan, sebagian simpatisan IM telah memutuskan bahwa baptisan adalah hal yang dapat dinegosiasi dan bukanlah suatu mandat Alkitab. ${ }^{82}$ Untuk pembahasan kita dalam artikel ini, cukuplah untuk mengatakan bahwa keutamaan kebudayaan yang dipakai sebagai paradigma penafsiran menghasilkan perubahan yang menggelisahkan mengenai pertanyaan-pertanyaan eklesiologi yang penting. ${ }^{83}$ Hermeneutika IM memutarbalikkan budaya dan wahyu, membawa otoritas wahyu Alkitab di bawah otoritas agama dan kebudayaan, bukan agama dan kebudayaan di bawah otoritas penuh wahyu

\footnotetext{
$81 \quad$ Ibid., 45.

82 Lihat Phil Parshall, Muslim Evangelism: Contemporary Approaches to Contextualization (2 ${ }^{\text {nd }}$ ed.; Colorado Spring: Biblica, 2003), 199-210. Lihat juga, H. L. Richard, “Unpacking the Insider Paradigm: An Open Discussionon Points of Diversity", IJFM 26:4 (2009): 180; Higgins, "Inside What?" 74-91. Bill Nikides mengkritik Kevin Higgins dan Donald McGavran karena mereka menjadikan sakramen sebagai sesuatu yang kurang bernilai di dalam praktik gereja. Bill Nikides, "A Response to Kevin Higgins' 'Inside What? Church, Culture, Religion and Insider Movements in Biblical Perspective'", SFM 5:4 (2009): 98n8.

83 Kerangka teologi dan analisis yang ada di tulisan-tulisan C-5 sangat dipengaruhi oleh individualisme Barat dan privatisasi iman yang cenderung menjauhkan doktrin soteriologi dan eklesiologi.
} 
Alkitab. Sekali lagi, usaha untuk mengontekstualkan Injil secara halus harus dihargai; tetapi cara di mana hal ini dilakukan mengharuskan kita untuk mempertanyakan arti otoritas Kristus. ${ }^{84}$

Di samping itu, menurut Alkitab (mis. Keluaran 20:4-6; Ulangan 4:2; Markus 7:6-9), aktivitas ibadah - bahkan aktivitas ibadah yang paling saleh sekalipun - yang tidak diwahyukan oleh Allah bagi umat-Nya adalah agama palsu. ${ }^{85}$ Itu adalah penyembahan berhala. Seperti yang Paulus katakan, semangat tanpa pengetahuan adalah kesesatan. Selain itu, jikalau penyembahan berhala tidak didefinisikan menurut apa yang seseorang lakukan (agama), lalu apa yang menjadi ciri-ciri yang menentukannya? Penyembahan berhala dalam hati adalah penyembahan berhala dalam kehidupan yang sebenarnya; praktik hidup menyatakan komitmen hati yang paling dalam. Bayangkan, seandainya, Elia memanggil nabi-nabi Baal (1 Raja-raja 18) untuk menyembah Allah Yahweh dan mendorong mereka untuk melakukan hal tersebut di kuil-kuil mereka, di atas altar-altar mereka, dan sesuai dengan praktik-praktik kafir yang mereka kenal. Proposal semacam ini sungguh sangat tidak masuk akal. Tetapi ide bahwa seorang Muslim yang telah bertobat dan dapat mempraktikkan lima pilar Islam adalah Injil IM.

84 Otoritas Yesus ("Tuhan kita yang mulia", Yak. 2:1) adalah faktor tunggal yang membentuk agama yang didefinisikan oleh Injil yang "murni dan tak bercacat di hadapan Allah, Bapa kita" (Yak. 1:27a), dan mempersatukan gereja-Nya (1Ptr. 1:22-23). Agama Alkitabiah "harus berada sesuai dengan standar ilahi (para tōtheōkai patri, 'di hadapan Allah dan Bapa'), dan sehingga dapat diterima di hadirat-Nya - ketaatan religius berkaitan dengan 'Allah Bapa Kita' yang dapat diterima" (D. Edmond Hiebert, James [Chicago: Moody, 1992], 126).

85 Untuk pembahasan mengenai otoritas dan pengajaran Alkitab mengenai ibadah (yaitu, "prinsip regulatif"), lihat Hughes Oliphant Old, Worship Reformed according to Scripture (rev. and expanded ed.; Louisville: Westminster John Knox, 2002); Phillip Graham Ryken, Derek W. H. Thomas, J. Ligon Duncan III, eds., Give Praise to God: A Vision of Reforming Worship (Phillipsburg: Presbyterian \& Reformed, 2003), 17-105; Terry L. Johnson, Reformed Worship: Worship That Is according to Scripture (Greenville: Reformed Academics, 2000); G. I. Williamson, "The Regulative Principle of Worship", http://www.nethtc.net/ giwopc/documents/RPW .pdf (diakses 20 Mei 2012). 
Relativisme semacam ini bukan hanya memengaruhi perihal praktik komunal, tetapi juga integritas dan moralitas pribadi. Contoh, keprihatinan para pendukung IM atas pengucapan syahadat ("Saya bersaksi bahwa tiada ilah selain Allah dan saya bersaksi bahwa Mohammad adalah rasul Allah"). Beberapa orang berpendapat bahwa karena Muslim Mesianis tidak benarbenar percaya kalimat tersebut atau menerimanya sebagaimana seorang Muslim, mengulangi perkataan pertobatan untuk Islam dapat diterima. Merespons tuduhan pelanggaran integritas, Rich Brown mencoba untuk membedakan antara ketidakjujuran dan kepura-puraan (dissimulation); ${ }^{86}$ tokoh lainnya, seperti Saudara Yusuf, bersikeras, "mengucapkan syahadat tidak merusak saksi mereka yang percaya tentang Yesus. Sebaliknya, hal tersebut memungkinkan untuk pemberitaan Yesus." 87 Keputusan mengenai hak untuk mengafirmasi - dengan atau tanpa ketulusan - komponen dari lima pilar Islam yang paling penting ini datang dari konteks budaya, nilainilai pragmatis, atau preferensi (rasa takut?) pribadi. Ironisnya, dengan ketergantungannya yang berlebihan kepada budaya, kelompok masyarakat, dan agama, paradigma IM justru menyokong individualisme barat yang sulit dihilangkan. ${ }^{8}$ Penentu cara di mana Injil mengonfrontasi kebiasaan agama seseorang berada di tangan pengikut Kristus yang baru dan bukan pada suara Allah yang berotoritas di dalam Alkitab atau bahkan pada komunitas dari pengikut-pengikut Yesus.

\footnotetext{
86 "Beberapa orang Muslim Mesianis mengucapkan syahadat, tetapi tidak semua dari mereka merupakan orang percaya yang sejati. Beberapa di antaranya hanya berpura-pura menyembunyikan pemikiran dan niatnya. Hal tersebut tidak sama dengan penipuan, yang mengandung manipulasi dan pengeksploitasian orang lain daripada hanya penyesuaian sosial atau perlindungan diri." Tanggapan Rick Brown terhadap Gary Corwin dalam tulisan Gary Corwin, "A Humble Appeal to C5/Insider Movement Muslim Ministry Advocates to Consider Ten Questions", IJFM 24:1 (2007): 12. Artikel ini berisi tanggapan-tanggapan dari lima pendukung IM.

87 Saudara Yusuf juga memberikan tanggapan kepada Corwin di Corwin, "A Humble Appeal", 12.

88 Karena otonominya yang dibatasi, maka relativisme berubah menjadi individualisme.
} 
Maka tidaklah mengejutkan bila manifestasi dari pemikiran IM seperti ini sangat beraneka ragam sebagaimana kesimpulan mengenai perbedaan kebudayaan dan agama menjadi sama tidak terhitung jumlahnya seperti jumlah penafsir itu sendiri. Relativitas berkuasa, sebagaimana setiap kesimpulan IM menekankan kesalahan epistemologi dan interpretasi hermeneutika IM. Secara tidak langsung, IM menjungkirbalikkan otoritas Alkitab, doktrin Kristen, moralitas Kristen, dan pengajaran eksplisit Alkitab mengenai gereja.

Kesucian yang Direlativisasikan di Dalam Gereja yang Telah Direlativisasikan

Menyusun pembelaan untuk Injil yang murni dan berkuasa, Lewis menuliskan, "Di Kitab Roma, pasal 6-15, Paulus menjelaskan bahwa Injil adalah kuasa perubahan di dalam hidup seorang percaya." 89 Hal ini memang benar, tetapi tidak seperti Lewis, Paulus tidak pernah menghapus Injil dari keseluruhan konteks perjanjian di dalam wahyu Alkitab. Anugerah menjadi anugerah karena Hukum menyatakan kesalahan secara objektif dan ilahi. Status bersalah di hadapan Allah ada di dalam konteks hukum yang baik dan kudus ini (1 Timotius 1:8; Roma 7:12) sehingga anugerah yang nyata dan Alkitabiah ini menjangkau orang yang berdosa. Anugerah Alkitabiah yang nyata datang kepada seseorang yang telah mengalami kerusakan oleh dosa seperti yang dikatakan oleh Alkitab. Sebagaimana Paulus memberitakan Injil, kesatuan vital dengan Kristus - satu-satunya Orang yang telah menaati hukum secara sempurna (Yohanes 6:38, 15:10; Roma 5:19; Galatia 4:1-6) - yang dihasilkan oleh Roh Kudus sehingga seorang yang sudah percaya menikmati hidup kebangkitan. Oleh karena itu, melalui anugerah Allah, setiap orang percaya menikmati hidup kebangkitan

89 Lewis, "Integrity”, 45. 
(1 Korintus 15:1-58) melalui kuasa Roh Kristus yang taat kepada kehendak Allah (Roma 13:8-14; Galatia 5:1-26; 1 Timotius 1:8-11; Yakobus 1:8-12) "menurut Injil yang mulia" (1 Timotius 1:11a).

Sebaliknya, Lewis menyampaikan suatu pendapat mengenai kuasa transformasi moral Injil dengan cara yang mengaburkan transformasi yang diperintahkan oleh Alkitab. Bagi Lewis, transformasi Injil terjadi secara internal dan misterius, tetapi paradigma IM-nya yang dikendalikan oleh kebudayaan telah mengosongkan Injil dari implikasi penuh atas hidup, kebudayaan, praktik agama, dan identitas seseorang. Bagi Lewis, di dalam pengabaian (agama dan kebudayaan) formal inilah maka Injil mempertahankan esensi kemurniannya dan integritasnya. Bagi Lewis, integritas Injil mengharuskan praktik-praktik eksternal untuk tetap didefinisikan secara budaya. Dengan formulasi ini, Lewis telah membedakan hati dan hidup, memisahkan kepercayaan terhadap Injil dari praktik Injil sebagaimana yang didefinisikan oleh firman Allah - "hukum yang memerdekakan" (Yakobus 1:19-25). Karena paling sedikit ada dua alasan mengapa wahyu PL dan PB tidak dapat menerima pemisahan ini.

Pertama, sebagaimana yang kita lihat dalam kesimpulan Paulus di Roma 1:1-7 (band. Galatia 3:8), Injil PB adalah Injil PL. Realitas Injil melampaui kedua Perjanjian tersebut. Ada perbedaan masa - yang satu adalah pengharapan dan yang lain adalah realisasinya; tetapi esensi Injil terus-menerus ada secara organik di setiap titik sejarah. Dengan melihat wahyu anugerah dari Kejadian sampai Wahyu, integritas hati/hidup dari PB adalah integritas hati/hidup dari PL, atau sebagaimana yang dikatakan oleh para Reformator, keselamatan senantiasa adalah karena iman semata-mata (faith alone) tetapi bukan karena iman yang sendirian (faith that is alone). Menurut kedua Perjanjian, iman yang bekerja adalah iman hidup dan nyata (Mazmur 1; Yakobus 2:14-26; Efesus 2:8-10; Galatia 5:6). Perbuatanperbuatan iman ini menemukan dasar mereka di dalam kehendak Allah yang dinyatakan, dan firman-Nya menjadi dasar untuk memahami dan 
menaati suara-Nya dengan iman. Identitas, iman, dan ketaatan secara organik saling meresap (interpenetrate) di dalam Injil yang Alkitabiah - di dalam masa PL dan PB-nya. Bagi orang percaya di segala zaman, Injil menyatukan hati dan hidup, sebagaimana iman kepada Penebus menuntut hidup dan praktik yang dibentuk oleh kehendak Sang Penebus (band. Keluaran 20:1-17; Roma 12:1-2).

Kedua, pernyatan Lewis mengenai "dua agama yang didasarkan pada Yesus Kristus yang berbeda secara radikal", selain membingungkan dalam hal bagaimana kita bicara mengenai kesatuan tubuh Kristus menggunakan istilah ini (band. Efesus 4:1-6), juga menunjukkan kegagalan di dalam menerima implikasi penuh dari hidup, kematian, dan kebangkitan Kristus demi umat Allah yang telah disatukan oleh Roh Kudus kepada Kristus dan disatukan satu dengan lainnya. Tekanan utama dari PB adalah persatuan secara eklesiologis - persatuan yang didasarkan di atas kesatuan kita dengan Kristus dan diwujudkan di dalam identitas, iman, dan menjalankan persekutuan bersama antara orang Yahudi dan bangsa-bangsa lain (Efesus 2:11-22; Yohanes 17:1-26; 1 Korintus 1:18-31). Rasul Paulus menyatakan secara eksplisit:

Karena Dialah damai sejahtera kita, yang telah mempersatukan kedua pihak dan yang telah merubuhkan tembok pemisah, yaitu perseteruan, sebab dengan mati-Nya sebagai manusia Ia telah membatalkan hukum Taurat dengan segala perintah dan ketentuannya, untuk menciptakan keduanya menjadi satu manusia baru di dalam diri-Nya, dan dengan itu mengadakan damai sejahtera, dan untuk memperdamaikan keduanya, di dalam satu tubuh, dengan Allah oleh salib, dengan melenyapkan perseteruan pada salib itu. Ia datang dan memberitakan damai sejahtera kepada kamu yang "jauh" dan damai sejahtera kepada mereka yang "dekat", karena oleh Dia kita kedua pihak dalam satu Roh beroleh jalan masuk kepada Bapa. Demikianlah kamu bukan lagi orang asing dan pendatang, melainkan kawan sewarga dari orangorang kudus dan anggota-anggota keluarga Allah, yang dibangun di atas dasar para rasul dan para nabi, dengan Kristus Yesus sebagai batu penjuru. Di dalam Dia tumbuh seluruh bangunan, rapi tersusun, menjadi Bait Allah yang 
kudus, di dalam Tuhan. (Efesus 2:14-21)

Kesatuan teologis yang dicapai oleh Kristus Yesus menentukan kesatuan fungsi, relasi, moral, dan gerejawi. Disatukan di dalam Kristus, umat Allah - Yahudi maupun bangsa lain - disatukan selamanya oleh Roh Kristus di dalam persatuan tujuan dan ibadah, iman dan praktik, identitas dan komunitas (Efesus 4:1-6). Realitas eskatologis di dalam Kristus menghasilkan persatuan eklesiologi dari umat Allah yang praktis - diakui, disadari, dinikmati, dan dipelihara.

Sebagaimana yang sudah dibahas, Lewis meninggikan otonomi kelompok orang lokal untuk menentukan bagaimana mereka menerima Yesus. Oleh karena itu, batasan-batasan IM akan tetap tidak jelas, dan himpunan terpusat IM dikaburkan oleh komitmennya yang sangat paradigmatik terhadap hegemoni kebudayaan. Tetapi kita tidak dapat untuk berbicara mengenai ketuhanan Kristus, otoritas Alkitab, dan transformasi spiritual di dalam-Nya terpisah dari tuntutan kehidupan yang nyata sebagaimana yang dijelaskan oleh Yesus dan para rasul - tuntutan yang membentuk praktik-praktik agama dan ibadah kita. Agama yang ditentukan oleh kebudayaan menghasilkan perpecahan yang tidak bisa dihindarkan; agama yang terpecah-belah menghasilkan gereja yang terpecah-belah, sesuatu yang melawan keseluruhan dorongan wahyu ilahi.

Meskipun benar bahwa pertobatan yang sejati adalah persoalan iman dan hati (Yohanes 3), tidak dapat disangkal juga hal tersebut adalah persoalan identitas baru (2 Korintus 5:16-21). Pengikut Kristus yang sejati akan menempuh jalan pemuridan, suatu jalan yang sempit (Matius 7:13-14) dan mahal (Lukas 9:23). ${ }^{90}$ Identitas Kristen di dalam gereja dan bentuk Perjanjian Baru dari identitas tersebut bukanlah pilihan opsional bagi

\footnotetext{
90 Lewis bersikeras menyatakan ("Honoring", 18) bahwa insider movements secara tepat "menegaskan bahwa seseorang tidak perlu harus melalui agama kekristenan, tetapi hanya melalui Yesus Kristus, untuk menjadi keluarga Allah".
} 
pengikut Kristus (Efesus 4:1-6). Gereja lebih dari sekadar sebuah komunitas orang-orang yang berkomitmen yang berada di dalam jaringan sosial atau agama yang sudah ada, yang menemukan berita dan identitas Yesus sangat meyakinkan dan berusaha untuk menarik Dia ke dalam susunan agama yang sudah ada. ${ }^{91}$ Raja di atas segala raja itu, yang di dalam kerajaan-Nya orang percaya sejati berada, yang menentukan identitas ini. Mempelai pria itu, yang adalah Kepala dari gereja-Nya, yang menentukan identitas ini. Kepala Gembala sang pemilik domba-domba, di pangkuan-Nya orang percaya sejati berada, yang menentukan identitas ini. Maka, Injil didistorsi ketika kita menerima pertobatan hati yang gagal mencakup panggilan atas identitas di dalam Kristus yang jelas dan vital (Kolose 3:1-17; Efesus 1:3-14, 4:17-5:21). "Singkatnya, identitas agama seseorang dengan Yesus Kristus menciptakan perpecahan yang harus ada dengan identitas Islam seseorang, atau identitas kita di dalam Yesus Kristus tidak akan ada artinya. Adalah suatu hal yang tidak etis untuk berlaku seakan-akan diskontinuitas ini tidak ada atau berlaku seakan-akan hal ini hanyalah masalah bentuk kebudayaan."92 Ketika identitas seorang Muslim (atau Budha atau Hindu) tetap dipegang pada saat dia mengikut Kristus, identitas personal dipisahkan dari identitas seseorang yang paling tinggi di dalam Kristus, menghasilkan skizofrenia agama yang tidak bisa dihindarkan. ${ }^{93}$

Bahwa Roh Allah mungkin dan memang bekerja melalui cara-cara yang tidak dapat kita bayangkan bukanlah suatu hal yang perlu dipertanyakan (lihat Yohanes 3). Bahwa Dia bekerja tanpa pertimbangan

91 Lihat Tim dan Rebecca Lewis, "Planting Churches: Learning the Hard Way", Mission Frontiers 31:1 (Januari-Februari 2009): 16-18.

92 Tennet, "Followers of Jesus", 113.

93 Lewis sering kali menjajarkan hal yang bersifat tetap (struktur sosial sebagai konteks bagi ekspresi iman) dan hal yang dinamis (hal-hal yang menjadi dan yang mengubah pengaruh iman terhadap struktur sosio-agama yang ada). Pertemuan antara elemen-elemen yang konstan dan dinamis yang tidak dijelaskan tersebut menghasilkan penutupan fakta yang tidak memuaskan. Lihat Lewis, "Honoring", 16. 
bagi gereja Kristus, yang didefinisikan secara Alkitabiah, adalah suatu hal yang tidak Alkitabiah. Selain itu, Alkitab menyatakan secara jelas bahwa kepemimpinan Kristus terkait secara langsung kepada gereja-Nya (lihat mis. Efesus 1:22-23; 5:23), dan Roh Kudus bekerja di dalam solidaritas yang absolut bersama dengan kehendak Bapa dan Anak (Yohanes 14:15-17, 25-31; 16:4-15; Roma 8:9-11). Terlebih lanjut, pengajaran yang diberikan kepada para rasul, yang menggarisbawahi sentralitas gereja di mana Yesus adalah Tuhan atasnya, juga menyatakan karakteristik gereja yang unik dan tidak dapat dinegosiasikan, termasuk organisasi yang Alkitabiah (Titus 1:5); perkumpulan yang teratur dan rutin (Ibrani 10:24-25); baptisan (Matius 28:18-20; Kisah Para Rasul 2:38-39); Perjamuan Kudus (1 Korintus 11:17-32); dan pemberitaan firman, persekutuan, dan doa (Kisah Para Rasul 2:42; 2 Timotius 4:1-2).

Secara singkat, melalui rasul-rasul-Nya Dia telah mendefinisikan tanda-tanda dan atribut-atribut gereja-Nya, suatu hal yang tidak bisa direduksi menjadi penyesuaian kebudayaan tanpa berpegang kepada integritas Alkitab. Tetapi, seruan para misionaris IM terdengar dari menaramenara misi: Yesus "sepertinya tidak terlalu memedulikan struktur-struktur atau bentuk-bentuk agama yang didirikan di dalam nama-Nya." 94 Bagi Lewis, wujud eklesiologi adalah suatu hal yang opsional; bentuk tersebut adalah entitas yang diputuskan oleh kebudayaan. ${ }^{95}$ Meskipun benar bahwa orang Barat telah memasukkan berbagai pola budaya di dalam bentukbentuk ibadah ${ }^{96}$ dan bahwa memasuki keluarga Allah melampaui sekadar memasuki institusi manusia, ini tidak berarti bahwa eklesiologi dan dinamika dari tubuh harus ditentukan oleh kebudayaan. Alkitab sebagai firman Allah yang diwahyukan tidak akan memperbolehkan terjadinya eklesiologi yang direlativisasikan dan dipisahkan karena konstruksi

\footnotetext{
94 Lewis, "Can the Kingdom", 15.

95 Band. Lewis, "Promoting", 76.

96 Kebudayaan yang lain juga telah melakukan hal yang sama.
} 
antropologi semacam ini.

\section{Misi yang Direlativisasikan}

Seperti yang telah dibahas, menurut paradigma penafsiran IM, keutamaan kebudayaanlah yang membentuk pengertian yang benar mengenai Alkitab. Menurut paradigma IM, keutamaan kebudayaan semacam ini juga harus secara komprehensif membentuk pemahaman kita mengenai konteks-konteks kontemporer. Mengapa? Karena satu-satunya cara yang benar untuk berinteraksi dengan analisis kebudayaan kontemporer adalah dengan mengakui adanya paralel antara konteks kebudayaan kita saat ini dan pada masa Alkitab. Cara interpretasi Alkitab berdasarkan konstruksi budaya IM menyebabkan seseorang mau tidak mau akan melihat aktivitas apostolik sebagai satu-satunya model aktivitas. Sebenarnya, menghormati otoritas Alkitab dilakukan dengan cara memahami paralel-paralel tersebut dan mencari cara untuk menggunakan paralel-paralel tersebut di ladang misi. Hermeneutika Perjanjian-BaruSebagai-Model yang dikendalikan oleh budaya ini memengaruhi argumentasi IM Lewis, dan ditekankan oleh analogi formatif yang sering dibuat di antara "gerakan iman kepada Kristus" masa kini dan "orangorang yang percaya pada abad pertama". ${ }^{97}$

Dengan membahas paralel-paralel kebudayaan dan penafsiran superfisial mengenai tindakan Yesus dan para rasul sebagai suatu fenomena yang dapat diulangi, kesimpulan misiologis dapat ditarik. Setelah menentukan bahwa praktik agama di dalam Alkitab bersifat netral dan dapat dinegosiasikan, para ahli IM bersikeras bahwa kita harus menganggap praktik-praktik agama kontemporer sama dengan ambivalensi "Injil". Apakah hasilnya? Alkitab menjadi buku manual how-to, dan

97 Lewis, "Integrity", 41, 42. 
beritanya tertutup di belakang struktur interpretasi budaya. Peristiwaperistiwa yang tak terulang lagi dan tak tertandingi di dalam sejarah keselamatan menjadi paradigma; dan sungguh disayangkan, hal-hal teologis yang penting menjadi hal-hal yang dapat dinegosiasikan secara budaya. Dengan metode IM seperti ini, pertanyaan budaya mengenai bagaimana misi dapat menggantikan pertanyaan untuk siapakah misi tersebut dilakukan. Ketuhanan Yesus Kristus tunduk kepada kekuasaan kebudayaan, menjadikan identitas agama berada di luar cakupan penebusan dan otoritas pemerintahan Kristus dan menciptakan berbagai perbandingan dan kesimpulan trans-kontekstual yang salah.

Paralel-paralel yang di buat Lewis memang jelas karena paralelparalel tersebut terbukti naif secara Alkitabiah. ${ }^{98}$ Dengan mengakui bagaimana sebagian orang Kristen barat menolak tradisi-tradisi agama lain, Lewis mendorong kita untuk melihat bagaimana konteks kita sejajar dengan konteks orang-orang Yahudi di abad pertama; seperti orang-orang percaya Yahudi mula-mula, kita memiliki "2.000 tahun pengajaran dan tradisi berharga milik kita sendiri yang ingin kita kembangkan." 99 Dengan menggunakan hermeneutika yang merelativisasikan, hermeneutika yang memfasilitasi paralel-paralel secara kontekstual dan metodologis, Lewis sekali lagi menggunakan alasan integritas Injil. Sama seperti Paulus dan rasul-rasul lainnya, "Saat ini kita memiliki kesempatan untuk menegaskan kembali kuasa Injil untuk bergerak masuk ke dalam kerangka budaya dan agama lain, dan mentransformasi mereka dari dalam."100 Maka, menurut Lewis dan pendukung IM lainnya, tanggung jawab kita adalah untuk mengerti bagaimana rasul-rasul menolak untuk memaksakan praktik-

\footnotetext{
98 Lewis membahas paralel trans-kontekstual di bagian lain: "Bisakah kita melihat bahwa orang-orang Muslim adalah seperti orang Samaria, dengan rumpun agama yang berasal dari Abraham, dan orang-orang Hindu seperti bangsa-bangsa lain, dengan berhala-berhala dan kuil-kuil mereka?" ("Honoring", 19).

99 Lewis, "Integrity", 44.

100 Ibid., 47.
} 
praktik agama kepada orang-orang percaya dari bangsa-bangsa lain, untuk menyetujui bahwa agama-agama lainnya dapat diterima, dan untuk mengikuti rasul-rasul yang memperbolehkan aktivitas-aktivitas agama yang ada pada kebudayaan lain untuk menjadi parameter bagi identitas agama baru dan "transformasi Injil." Kalau kita tidak melakukan hal ini, "kita sebenarnya sedang menggerogoti integritas Injil."101

Pakar dan pelaku misi IM menyatakan keinginan mereka yang tulus untuk menyebarkan berita mengenai Yesus Kristus. Pada tingkatan yang penting, kita menghargai fokus vital mereka, yang sering diabaikan, mengenai peluasan Kerajaan Allah. Berapa sering orang Kristen di barat telah dengan nyamannya masuk ke gereja tetapi tidak tertarik untuk keluar dari gereja untuk mencapai orang-orang di dunia yang belum terjangkau. Sudah pasti, Kisah Para Rasul dan surat-surat menyatakan secara lantang perkembangan dan ekspansi Injil dan memanggil seluruh gereja di sepanjang zaman untuk bertindak (Kisah Para Rasul 1:8-9; band. Matius 28:18-20). Pekerjaan pemberitaan Injil yang tidak mengenal rasa takut, rasa capai, dan ekspansif sebagaimana yang dinyatakan di dalam tindakan orang-orang percaya abad pertama di bawah pimpinan rasul-rasul memberikan kepada kita suatu model yang menarik dan meyakinkan untuk gereja abad keduapuluh satu.

Akan tetapi, Dennis Johnson secara bijak memperingatkan kita mengenai dua posisi ekstrem di dalam menafsir Kisah Para Rasul. Di satu sisi, beberapa orang melihat Kisah Para Rasul berfungsi sebagai model; semua yang diceritakan di Kisah Para Rasul dapat terulang kembali di gereja saat ini. Di lain pihak, beberapa orang memaksakan Kisah Para Rasul masuk ke dalam sejarah yang tidak ada relevansinya, di mana "walaupun Kisah Para Rasul secara akurat memaparkan masa pertumbuhan gereja,

101 Ibid. 
pemaparan ini tidak seharusnya mengarahkan kehidupan kita saat ini."102 Dengan berusaha untuk menghormati teologi PB yang limpah dan relevan, realitas-realitas gereja abad pertama yang tidak dapat ditiru, dan genre sejarah dari Injil Lukas dan Kisah Para Rasul, Johnson secara bijak memberikan jalan tengah (via media). Lukas menuliskan sejarah yang "harus menghasilkan perbedaan di dalam iman dan kehidupan kita, sama seperti Paulus, memaparkan tujuan dari sejarah Perjanjian Lama sebagai instruksi etis (1 Korintus 10:11) dan pengajaran etis (Roma 15:4; lihat juga 2 Timotius 3:16)."103 Secara singkat, aplikasi dari Kisah Para Rasul (dan dalam hal ini seluruh PB) harus dilakukan dengan suatu pandangan kepada peristiwaperistiwa yang unik: kehidupan, kematian, dan kebangkitan Yesus Kristus di dalam sejarah. "Kita perlu berhati-hati . . agar kita jangan sampai . . berpikir bahwa hanya karena penulis mencatat bagaimana beberapa orang memberikan respons terhadap peristiwa-peristiwa tertentu di dalam narasi tersebut maka kita juga harus memiliki respons yang sama sekarang."104 Aplikasi dan ketaatan adalah penting; tetapi mereka harus tumbuh dari penghargaan terhadap peristiwa-peristiwa yang memiliki signifikansi kosmik dan tak terulangi lagi. Wahyu mengenai Yesus Kristus ini membakar semangat penulis-penulis $\mathrm{PB}$, menetapkan keseluruhan berita radikal mereka (1 Korintus 1:18-31), dan mengarahkan metode mereka yang kelihatannya sederhana (1 Korintus 2:1-5). Di atas dasar karya Allah di dalam Kristus yang tak terulang dan pemberitaan setia rasul-rasul yang

102 Dennis E. Johnson, The Message of Acts in the History of Redemption (Phillipsburg:

Presbyterian \& Reformed, 1997), 4. Johnson mendesak para pembacanya untuk membaca Kisah Para Rasul dengan mengingat tujuan Lukas untuk menunjukkan apa yang Allah telah lakukan di dalam Kristus; membaca Kisah Para Rasul dengan pandangan kepada teologi surat-surat PB; membaca Kisah Para Rasul dengan cara yang menghormati strukturnya yang berakar dalam di PL, gaya penulisan dan teologi Yahudi; membaca Kisah Para Rasul dalam hubungannya dengan Injil Lukas; membaca Kisah Para Rasul menurut struktur rambu-rambunya (5-13). 103 Ibid., 5.

104 Walter L. Liefeld, Interpreting the Book of Acts (Guides to New Testament Exegesis; Grand Rapids: Baker, 1995), 58. 
berpusat pada Kristuslah kita sekarang memproklamasikan ke-Tuhan-an Kristus atas segala suku bangsa (band. Filipi 2:5-11).

Oleh karena itu, sebagai Tuhan yang dibangkitkan dan ditinggikan (Filipi 2:1-11), Yesus Kristus dengan otoritas-Nya mendefinisikan semua hal (Matius 28:18), termasuk eklesiologi dan misiologi kita. Karena alasan ini, untuk motivasi misi yang dinyatakan, kita tidak berada dalam posisi untuk menetralkan budaya atau untuk memperkenalkan gerakan-gerakan yang tidak memiliki kejelasan mengenai Injil Alkitabiah sepenuhnya, mengenai ajaran Alkitab tentang otoritas Alkitab itu sendiri, dan natur dan praktik gereja, termasuk mengenai sakramen-sakramennya. Semua ini merupakan persoalan doktrin dan eklesiologi yang telah ditetapkan oleh Allah, bukan persoalan kebudayaan, "struktur-struktur eklesiologis yang diciptakan oleh manusia"; 105 persoalan mengenai gereja dan tata caranya yang ditetapkan oleh Kristus adalah persoalan mengenai Injil juga. ${ }^{106}$ Dan demi menegakkan kemurnian Injil, proklamasi Injil harus mencakup ekspresi ajaran apostolik yang tidak berkompromi dan yang berpusatkan pada Kristus - demi praktik, doktrin, dan untuk kemajuan gereja yang universal.

\section{Kesimpulan}

Untuk para pendatang baru, pengajaran dan praktik IM sering menyebabkan goncangan dan kebingungan. Metode-metode inventif ini telah melahirkan respons-respons yang sengit, bukan saja dari orang-orang barat yang was-was, bahkan dari orang-orang Muslim yang telah percaya kepada Kristus. Edward Ayub, petobat Muslim dan pastor dari Bangladesh, menyesalkan praktik-praktik IM di negaranya. Dia berkata: “Sebagian orang ini tidak saja menasihatkan orang-orang untuk tetap menjadi orang Muslim

\footnotetext{
105 Lewis, "Can the Kingdom", 15.

106 Seorang petobat baru bukan hanya memiliki iman, dia juga dibawa masuk ke dalam iman yang umum" (Tennet, "Followers of Jesus", 111).
} 
daripada mengakui Kristus secara terbuka, mereka menasihati orang-orang yang telah meninggalkan Islam, setelah mereka menjadi Kristen, untuk bertobat kembali dan bergabung dengan masjid."107 Petobat Muslim lainnya, Adul Qurban, dengan tenang menggambarkan praktik IM yang dia saksikan:

Misionaris Kristen mendorong orang Muslim untuk menerima Yesus sebagai Juru Selamat mereka tetapi tetap menjadi Muslim dengan terus membaca Qur'an, mengucapkan syahadat ["Saya bersaksi bahwa tiada ilah selain Allah dan saya bersaksi bahwa Mohammad adalah rasul Allah"], dan turut mengambil bagian di dalam aktivitas masjid. Mereka menjaga iman mereka kepada Kristus secara rahasia, dan hanya mereka nyatakan (sedikit banyak) kalau orang Muslim lainnya menanyakan kepada mereka mengenai Yesus. Dengan menjaga identitas Muslim mereka (dan bahkan kepercayaan mereka), tetapi mengaku percaya kepada Injil, orang-orang Muslim ini tetap tinggal di dalam komunitas mereka, menunggu potensi untuk menjadi saksi bagi sesama orang Muslim. ${ }^{108}$

IM tidak lagi berada di dalam inkubasi, IM telah menetas menjadi keyakinan yang matang, dipraktikkan, dan disetujui. Praktiknya yang terus menjalar ke seluruh dunia melalui banyak misionaris-misionaris, agen-agen misi, dan warga negara biasa yang diyakinkan olehnya, telah menciptakan krisis misiologi, eklesiologi, dan eksistensial. Keberadaannya yang kuat adalah alasan mengapa orang Kristen di seluruh dunia seperti Edward Ayub dari Bangladesh memohon gereja barat untuk menghadapi dan memerangi praktik ini, meminta para provokator untuk berhenti. Apa yang harus kita katakan kepada para pendukung IM mengenai berita dan metode mereka?

Sebagai penutup, kita kembali kepada substansi dari peringatan Lewis bahwa "kita tidak boleh meremehkan diskusi ini [mengenai mereka yang percaya kepada Kristus tanpa mengidentifikasikan diri mereka sebagai orang Kristen] sebagai kontekstualisasi radikal baru atau strategi misi baru yang dirancang untuk mempermudah orang-orang Muslim datang kepada

\footnotetext{
107 Ayub Edward, "Observations and Reactions to Christians Involved in a New Approach to Mission", in Chrislam, 256.

108 "Flirting with Frankenstein: Insider Movements from the Inside", in Chrislam, 238.
} 
Kristus. Ada hal yang lebih penting yang sedang dipertaruhkan: integritas Injil itu sendiri."109 Saya setuju. Injil sedang dipertaruhkan, dan kita tidak boleh meremehkannya. Tetapi inilah inti permasalahannya: Definisi Lewis mengenai Injil dan ekspresi kontemporernya adalah peremehan terhadap Injil.

Alkitab jelas ditulis kepada dan di dalam konteks budaya; karya penebusan Allah dan kata-kata interpretatif-Nya nyata terjadi di dalam sejarah. ${ }^{110}$ Maka, kita menerima keberadaan faktor budaya di dalam Alkitab, bahkan termasuk semua yang mengandung kesulitan di dalam interpretasi (mis. tudung kepala di 1 Korintus 11). Tetapi, karena Alkitab secara organik berpusat kepada Yesus Kristus, substansi teologi yang telah diatur secara ilahi harus menentukan parameter-parameter dari faktor budaya yang bersifat temporal. Maka, kebudayaan harus dilihat menurut otoritas Alkitab dalam menafsirkan dirinya sendiri, bukan Alkitab ditafsir menurut otoritas budaya. Tunduk kepada otoritas Alkitab berarti memperbolehkan Alkitab untuk mendefinisikan hermeneutikanya sendiri daripada (sadar atau tidak) memaksakan hermeneutika asing kepadanya. ${ }^{111}$ Kanon ilahi ini melampaui dan mengalahkan kanon budaya apa pun.

Dengan semua ketekunan yang rendah hati, murid-murid misi tidak boleh membaca PB melalui lensa antropologi budaya, kalau pun motivasi dalam melakukan hal ini adalah untuk kepentingan misi. Tetapi, antropologi harus tunduk kepada pengujian Alkitab dan Kristus di dalam Alkitab. Perbedaan ini bukan persoalan taktik atau semantik; ini adalah persoalan mempertahankan integritas Injil. Metode apa pun yang mencampurkan Yesus Tuhan dengan praktik agama orang yang tidak percaya, bukanlah

\footnotetext{
109 Lewis, "Integrity", 46.

110 Lihat Geerhardus Vos, "The Idea of Biblical Theology as a Science and as a Theological Discipline", di Redemptive History and Biblical Interpretation: The Shorter Writings of Geerhardus Vos (ed. Richard B. Gaffin Jr.; Phillipsburg: Presbyterian \& Reformed, 1980), 3-24.

111 Pengakuan Iman Westminster 1.9 menyatakan dengan baik bahwa otoritas interpretif final Alkitab: "Kaidah yang tidak dapat keliru dalam menafsirkan Alkitab adalah Alkitab itu sendiri."
} 
misi Alkitabiah; itu adalah sinkretisme. Sadar akan bahaya sinkretisme, Lewis menyimpulkan bahwa kekuatiran ini dapat dihilangkan dengan menyediakan terjemahan Alkitab yang "efektif dan akurat", dengan cara memasukkan "arti baru" ke dalam "praktik-praktik budaya lokal dan bahkan ritual-ritual agama", dengan menolak memberikan tekanan kepada orang Kristen lain untuk tunduk kepada bentuk-bentuk agama tertentu, dan dengan melawan godaan untuk mengendalikan "gerakan Yesus" ("Jesus movements") di dalam kebudayaan selain kebudayaan kita sendiri. ${ }^{112}$ Tetapi, cara-cara ini tidaklah cukup, karena hermeneutika budaya IM mengatur proposal-proposal itu sendiri. Selain itu, menilai sinkretisme melalui lensa teologi yang sudah disinkretiskan akan menodai analisis tersebut.

Pada akhirnya, penilaian IM harus sesuai dengan otoritas Alkitab dan definisi Alkitab sendiri mengenai Injil di dalam struktur teologis, eskatologi, dan eklesiologinya yang limpah. Paradigma interpretif IM Lewis membungkam suara Injil dan gagal melewati tes pemeriksaan Alkitab. Memaksakan Hermeneutika Perjanjian-Baru-Sebagai-Model dalam bingkai budaya atas Kitab Suci, teori IM sebagaimana yang dijelaskan oleh Lewis gagal membaca Alkitab secara Alkitabiah, merampok firman Tuhan dari kesatuan organik yang berpusat pada perendahan (humiliation) dan pemuliaan (exaltation) Yesus Kristus, dan menarik kesimpulan mengenai Injil dan proklamasinya yang pasti mengaburkan praktik dan doktrin Alkitab. Dengan menyerahkan otoritas tertinggi kepada analisis budaya, para pendukung IM telah melakukan pendefinisian ulang terhadap isi dan perilaku Injil, sekaligus cara-cara untuk memajukan "Injil" ini. Dan di dalam semuanya itu, pendefinisian ulang ini telah menjadikan "Injil" ini tidak dapat dikenali secara Alkitabiah. Menjawab pertanyaan penting di dalam tulisan ini, kami menyesalkan bahwa "Injil" yang dikhotbahkan melalui konstruksi IM ini bukanlah mengenai Injil Yesus Kristus, Anak dari Allah

112 Lewis, "Possible Pitfalls", 22-24. 
yang hidup, yang Alkitabiah, tetapi "injil lain yang sebenarnya bukan Injil” (Galatia 1:6b-7a). ${ }^{113}$

Tentu saja, Hakim kita yang akan datang, Tuhan yang empunya tuaian, akan secara sempurna memisahkan gandum dari lalang. Tetapi justru fakta yang mendesak inilah yang memaksa kita untuk percaya, melakukan, dan memproklamasikan Injil-Nya di dalam kemurnian Alkitabiah dan sesuai dengan integritas Alkitabiahnya. 